\title{
Sulphuric acid closure and contribution to nucleation mode particle growth
}

\author{
M. Boy ${ }^{1}$, M. Kulmala ${ }^{1}$, T. M. Ruuskanen ${ }^{1}$, M. Pihlatie ${ }^{1}$, A. Reissell ${ }^{1}$, P. P. Aalto ${ }^{1}$, P. Keronen ${ }^{1}$, M. Dal Maso ${ }^{1}$, \\ H. Hellen ${ }^{2}$, H. Hakola ${ }^{2}$, R. Jansson ${ }^{3}$, M. Hanke ${ }^{4}$, and F. Arnold ${ }^{4}$ \\ ${ }^{1}$ University of Helsinki, Dept. Physical Sciences, P.O. Box 64, FIN-00014 Univ. of Helsinki, Finland \\ ${ }^{2}$ Finnish Meteorological Institute, Air Quality Research, Sahaajankatu 20 E, FIN-00880 Helsinki, Finland \\ ${ }^{3}$ Stockholm University (ITML), Air Pollution Laboratory, Institute for Applied Environmental Research, Stockholm \\ University, S-10691 Stockholm, Sweden \\ ${ }^{4}$ Atmospheric Physics Division, Max-Planck Institute for Nuclear Physics, (MPIK), P.O. Box 103980, D-69029 Heidelberg, \\ Germany
}

Received: 23 June 2004 - Published in Atmos. Chem. Phys. Discuss.: 7 October 2004

Revised: 21 December 2004 - Accepted: 3 March 2005 - Published: 16 March 2005

\begin{abstract}
Sulphuric acid concentrations were measured and calculated based on pseudo steady state model with corresponding measurements of $\mathrm{CO}, \mathrm{NO}_{\mathrm{x}}, \mathrm{O}_{3}, \mathrm{SO}_{2}$, methane and non-methane hydrocarbon (NMHC) concentrations as well as solar spectral irradiance and particle number concentrations with size distributions. The measurements were performed as a part of the EU project QUEST (Quantification of Aerosol Nucleation in the European Boundary layer) during an intensive field campaign, which was conducted in Hyytiälä, Finland in March-April 2003. In this paper, the closure between measured and calculated $\mathrm{H}_{2} \mathrm{SO}_{4}$ concentrations is investigated. Besides that, also the contribution of sulphuric acid to nucleation mode particle growth rates is studied. Hydroxyl and hydroperoxy radical concentrations were determined using a pseudo steady state box model including photo stationary states. The maximum midday $\mathrm{OH}$ concentrations ranged between $4.1 \times 10^{5}$ to $1.8 \times 10^{6}$ molecules $\mathrm{cm}^{-3}$ and the corresponding values for $\mathrm{HO}_{2}$ were $1.0 \times 10^{7}$ to $1.5 \times 10^{8}$ molecules $\mathrm{cm}^{-3}$. The dominant source term for hydroxyl radicals is the reaction of $\mathrm{NO}$ with $\mathrm{HO}_{2}(56 \%)$ and the reaction of $\mathrm{CO}$ with $\mathrm{OH}$ covers around $41 \%$ of the sinks. The sulphuric acid source term is the reaction $\mathrm{SO}_{2}$ with $\mathrm{OH}$ and the sink term is condensation of sulphuric acid. The closure between measured and calculated sulphuric acid concentrations is achieved with a high agreement to the measured values. In sensitivity studies, we used different values for the non-methane hydrocarbons, the peroxy radicals and nitrogen dioxide. The best fits between calculated and measured values were found by decreasing the $\mathrm{NO}_{2}$ concentration when it exceeded values of $1.5 \mathrm{ppb}$ and doubling the non-methane hydrocarbon concen-
\end{abstract}

Correspondence to: $\mathrm{M}$. Boy

(michael.boy@helsinki.fi) trations. The ratio, standard deviation and correlation coefficient between measured and calculated sulphuric acid concentrations are $0.99,0.412$ and 0.645 , respectively. The maximum midday sulphuric acid concentrations varied between $3 \times 10^{5}$ to $1.9 \times 10^{7}$ molecules $\mathrm{cm}^{-3}$ for the measurements and $3 \times 10^{5}$ to $1.4 \times 10^{7}$ molecules $\mathrm{cm}^{-3}$ for the calculations, respectively. An average participation of sulphuric acid to the nucleation mode particle growth rates is $8.8 \%$. Classifying the days into two groups - "polluted" days with air masses originated over Central Europe or UK, and "cleaner" days with air masses originated over the Northern Atlantic or the Polar regions - reflects an equal sulphuric acid contribution to the aerosol growth in both air mass classes.

\section{Introduction}

Aerosol particles are ubiquitous in the Earth's atmosphere and influence our quality of life in many different ways. In urban environments, aerosol particles can affect human health through their inhalation (Wichmann and Peters, 2000; Stieb et al., 2002). In a global troposphere, and particularly downwind from major pollution sources, aerosol particles are thought to contribute to climate change patterns ( $\mathrm{Ra}$ manathan et al., 2001; Menon et al., 2002). Understanding these effects requires detailed information on how aerosol particles enter the atmosphere and how they are transformed before being removed by dry or wet deposition. Key processes in this respect are the formation of new atmospheric particles and their subsequent growth to larger sizes.

In recent years the formation and growth of nanometersize atmospheric aerosol particles have been observed at many different sites. These measurements have been 
performed on ships, aircraft and fixed sampling sites during both intensive campaigns and continuous ground-based measurements. From measured size distributions one can infer the particle growth rate, whereas from measured number concentrations an apparent source rates of $3 \mathrm{~nm}$ (or $10 \mathrm{~nm}$ or $15 \mathrm{~nm}$ ) particles is obtained. Globally, the formation of new particles and their subsequent growth seem to occur almost everywhere (Kulmala et al., 2004a).

Sulphuric acid is the best candidate as regards the ability of individual molecules to produce new particles in the atmosphere (Kulmala, 2003; Kulmala et al., 2004a). It will participate in binary, ternary and ion induced nucleation. A technique for the measurement of gas phase sulphuric acid at concentrations as low as $10^{4} \mathrm{~cm}^{-3}$ is available (Eisele and Tanner, 1993). However, it is still very rare that sulphuric acid is measured in relation to atmospheric aerosol formation (Kulmala et al., 2004a).

Within the framework of the EU project QUEST (Quantification of Aerosol Nucleation in the European Boundary layer), continuous measurements of aerosol size distributions and three intensive field campaigns in Finland (Hyytiälä), Italy (San Pietro Capofiume) and Ireland (Mace Head) were carried out. During the campaign in Hyytiälä (17 March to the 13 April 2003), besides many other parameters, sulphuric acid concentrations were measured continuously on 21 days. Sulphuric acid is one participant of ternary nucleation by $\mathrm{H}_{2} \mathrm{O}, \mathrm{NH}_{3}$ and $\mathrm{H}_{2} \mathrm{SO}_{4}$ (Korhonen et al., 1999), one of the most common proposed mechanisms for atmospheric nucleation in the planetary boundary layer (Kulmala, 2003).

Although the precursors for sulphuric acid (at least some of them), as well as the condensation sink, have been measured in several places, the closure between measured and calculated sulphuric acid concentrations has been investigated rarely (Weber et al., 1997 and Eisele et al., 1993). In this paper we calculated sulphuric acid concentrations using a pseudo steady state box model including photo stationary states (see Seinfeld and Pandis, 1998). Here we focus on a comparison between field measurements and model calculations of sulphuric acid concentrations using the data obtained in the field campaign in Hyytiälä. We also investigate the contribution of sulphuric acid to the growth rate of nucleation mode particles. Therefore, hydroxyl and hydroperoxy radical concentrations were calculated with the input values of different gases measured during the campaign. We focused hereby only on daytime chemistry, because no nighttimes measurements of $\mathrm{NO}_{3}$ are available and second because the formation of new particles and high growth rates appear only during daylight (Boy et al., 2003).

\section{Experiment}

\subsection{SMEAR II}

Data were collected at the Station for Measuring Forest Ecosystem-Atmosphere Relations (SMEAR II) in Hyytiälä, Finland. The station is located in Southern Finland $\left(61^{\circ} 51^{\prime} \mathrm{N}, 2^{\circ} 17^{\prime} \mathrm{E}, 181 \mathrm{~m}\right.$ a.s.l.), with extended areas of Scots Pine (Pinus sylvestris) dominated forests. The conditions at the site are typical for a background location. However, the station buildings ( $0.5 \mathrm{~km}$ away) and the city of Tampere $(60 \mathrm{~km}$ away - both located in a west-south-west direction from the instruments, $215-265^{\circ}$ ) occasionally polluted measurements.

In the framework of this work measurements of spectral solar irradiance, different gas concentrations $\left(\mathrm{O}_{3}, \mathrm{H}_{2} \mathrm{O}\right.$, $\mathrm{NO}, \mathrm{NO}_{\mathrm{x}}, \mathrm{CO}$ and $\mathrm{SO}_{2}$ ), temperature, humidity, winddirection, particle number concentration and size distribution were taken into account. For a more detailed description of SMEAR II and instrumentation, we refer to Kulmala et al. (2001) and http://www.honeybee.helsinki.fi/smear/.

\subsection{Gaseous sulphuric acid measurements}

Sulphuric acid was measured by a chemical ionization mass spectrometer apparatus (CIMS) built by MPI-K Heidelberg. The instrument is essentially the same as the one used for measurements of atmospheric $\mathrm{OH}, \mathrm{HO}_{2}$ and $\mathrm{RO}_{2}$ radicals except for the chemical conversion parts (Hanke et al., 2002). In brief, the CIMS used in QUEST 2 consists of four major elements including an ion trap mass spectrometer, a flow reactor, an ion source, and an $\mathrm{H}_{2} \mathrm{SO}_{4}$-source used for calibration. Atmospheric air is passed through the flow reactor (at ambient atmospheric pressure). Reagent ions of the type $\mathrm{NO}_{3}-\left(\mathrm{HNO}_{3}\right)_{n}$ (with $\mathrm{n}$ being mostly 1 ) are produced in the ion source and subsequently introduced into the flow reactor. There these ions undergo ion-molecule reactions of the type $\mathrm{NO}_{3}-\left(\mathrm{HNO}_{3}\right)_{\mathrm{n}}+\mathrm{H}_{2} \mathrm{SO}_{4} \rightarrow \mathrm{HSO}_{4}-\left(\mathrm{HNO}_{3}\right)_{\mathrm{n}}+\mathrm{HNO}_{3}$ whose rate coefficients are close to the ion-molecule collision rate coefficients. Using the mass spectrometer the abundance ratio of product and reagent ions is measured. Building on this ion abundance ratio the $\mathrm{H}_{2} \mathrm{SO}_{4}$-concentration in the flow reactor is determined. The latter is typically only about $50 \%$ of the ambient atmospheric sulphuric acid concentration due to $\mathrm{H}_{2} \mathrm{SO}_{4}$-losses to the walls of the sampling line and the flow reactor. In order to quantify these $\mathrm{H}_{2} \mathrm{SO}_{4}$ losses an $\mathrm{H}_{2} \mathrm{SO}_{4}$-source is used for careful calibrations. Also carefully determined is the $\mathrm{H}_{2} \mathrm{SO}_{4}$-background signal of the CIMS-instrument, which dictates the $\mathrm{H}_{2} \mathrm{SO}_{4}$-detection limit.

During QUEST 2 the $\mathrm{H}_{2} \mathrm{SO}_{4}$-detection limit was as low as about $1 \times 10^{5}$ molecules $\mathrm{cm}^{-3}$ corresponding to an atmospheric mole fraction of $4 \times 10^{-15}$. The time-resolution of the sulphuric acid measurements was better than one second but usually sulphuric acid concentrations were integrated over $100 \mathrm{~s}$ to reduce the statistical error. The absolute 

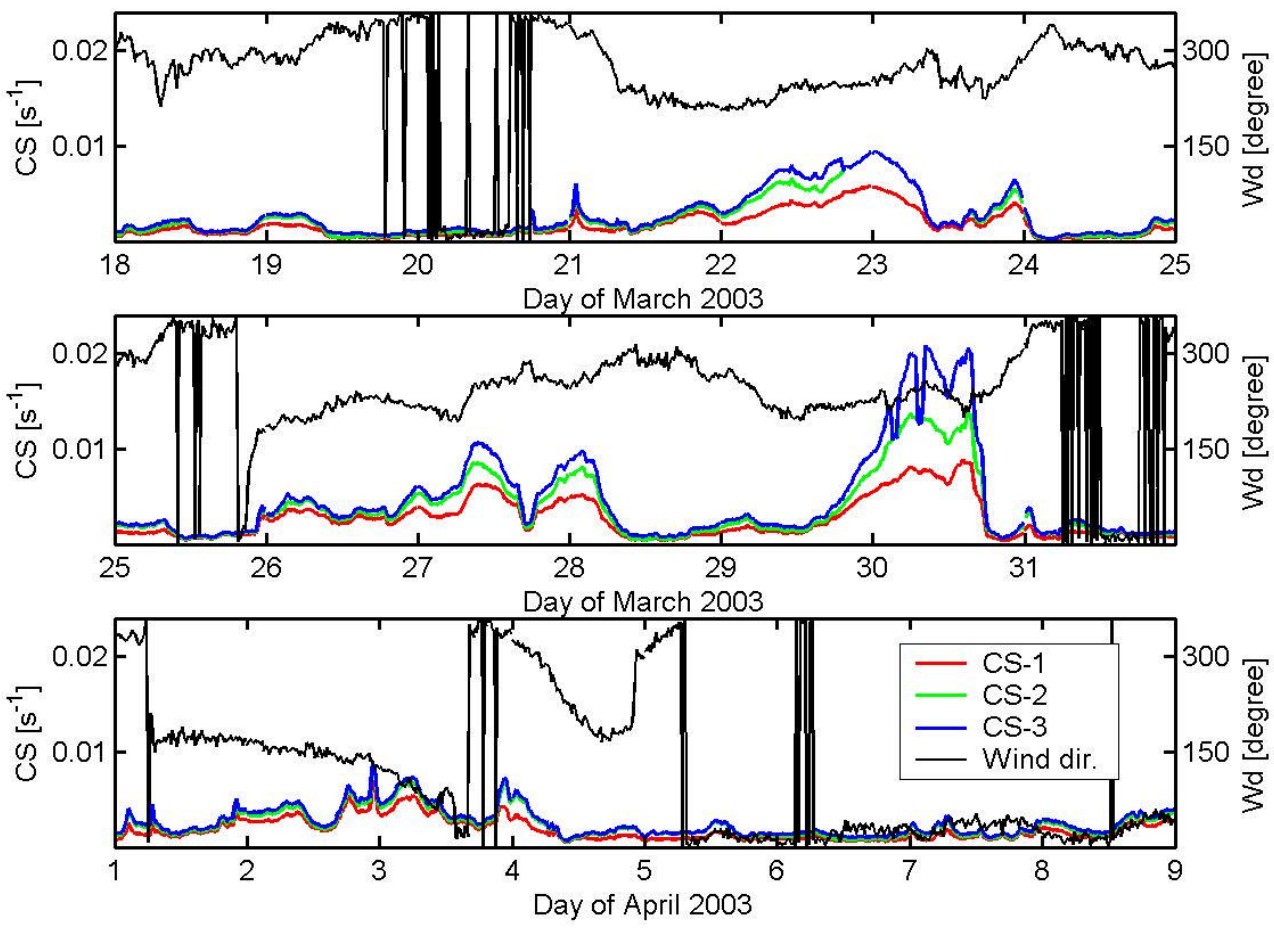

Fig. 1. Different calculated condensational sink values (explanation in Sect. 2.5) and wind-direction for Hyytiälä, Finland.

uncertainty of the measured $\mathrm{H}_{2} \mathrm{SO}_{4}$-concentration is plus or minus $31 \%$. A paper addressing in detail the CIMS used and the $\mathrm{H}_{2} \mathrm{SO}_{4}$-measurements made during the QUEST 2 campaign is in preparation (Sellegri et al., 2005).

\subsection{Methane}

Methane concentration was measured with a tunable diode laser trace gas analyser (TDL TGA100, Campbell Scientific Inc., USA) during the QUEST 2 campaign. The measurement system consisted of a TDL TGA100 and an ultrasonic 3-D anemometer (Solent 1012, Gill Ltd., Lymington, Hampshire, England). The sample air was drawn to the TDL at 5060 mbar pressure through a PD1000 drier (Perma pure Inc.) and a $10 \mathrm{~m}$ long sample tubing at a flow rate of $31 \mathrm{~min}^{-1}$. The measurements were conducted at $10 \mathrm{~Hz}$ frequency. The TDL was calibrated once during the campaign with calibration gases containing $0.004 \mathrm{ppm}$ and $1.831 \mathrm{ppm}$ of $\mathrm{CH}_{4}$. Methane measurements were conducted from 28 March to 23 April.

The average $\mathrm{CH}_{4}$ concentration during the measurement period was $1.941 \mathrm{ppm} \mathrm{CH}_{4}$. Variation in $\mathrm{CH}_{4}$ concentration was very small throughout the measurement period $\left(\mathrm{CH}_{4}\right.$ in ppm: average $=1.941, \max =1.988, \min =1.873$ ).

\subsection{Non-methane hydrocarbons and formaldehyde}

Ambient monoterpenes were sampled continuously throughout the sampling period on Tenax TA (200 mg in $1 / 4$ " stainless steel tubes, $50 \mathrm{Nml} \mathrm{min}^{-1}$, $120 \mathrm{~min}$ per sample). All sam- pling was done through a $1 / 2$ " ozone scrubber (4 plies $\mathrm{MnO}_{2}$ coated copper screens) and a $5 \mathrm{~cm}, 0.5 \mathrm{~mm}$ ID Teflon tube (to limit diffusion artefacts), placed immediately in front of each sample tube. A diffusion control tube, through which no sample flow was taken, was placed alongside the sample tubes. Twenty-four hour sampling was achieved by a system of timers, solenoid valves, and mass flow control and the sample tubes changed once a day. After sampling, the tubes were stored in a cool and dry environment. Analysis was performed by ATD-GC-MS (Automatic thermal desorption, gas chromatography and mass spectrometric detection and quantification). The main monoterpenes observed were $\alpha$-pinene and $\Delta 3$-carene, accompanied by camphene, $\beta$-pinene, myrcene and limonene.

Formaldehyde samples were collected by drawing air through C18-cartridges (Sep-Pak, Waters) coated with DNPH (2,4-dinitrophenyl hydrazine) and analyzed using a liquid chromatograph with a mass spectrometer (LC-MS). Sampling time was $24 \mathrm{~h}$ and flow rate $980 \mathrm{ml} \mathrm{min}^{-1}$. The measurements are described in more detail by Hellén et al. (2004).

In this work we will use only formaldehyde and monoterpenes as non-methane hydrocarbons, other NMHC's were not measured during the campaign. In Sect. 5 we will calculate in sensitivity studies the influence of different values of our measured NMHC's concerning the $\mathrm{OH}$-budget. 
Table 1. Daytime mean values of different parameters averaged between 9 a.m. and 3 p.m. (NMHC=non-methane hydrocarbons, UV-B=solar irradiance between $280-320 \mathrm{~nm}$, RH=relative humidity and CS=condensational sink values, 24-h average for HCHO).

\begin{tabular}{|c|c|c|c|c|c|c|c|c|c|c|c|c|}
\hline \multirow{2}{*}{ Date } & $\mathrm{H}_{2} \mathrm{SO}_{4}$ & $\mathrm{NO}_{2}$ & $\mathrm{SO}_{2}$ & $\mathrm{O}_{3}$ & NO & co & $\mathrm{HCHO}$ & NMHC & \multirow{2}{*}{$\frac{\text { Temp. }}{[\mathrm{K}]}$} & \multirow{2}{*}{$\frac{\text { UV-B }}{\left[\mathrm{W} \mathrm{m}^{-2}\right]}$} & \multirow{2}{*}{$\begin{array}{c}\mathrm{RH} \\
{[\%]}\end{array}$} & \multirow{2}{*}{$\frac{c s}{\left[s^{-1}\right]}$} \\
\hline & {$\left[10^{6}\right.$ molecules $\left.\mathrm{cm}^{-3}\right]$} & \multicolumn{7}{|c|}{$\left[10^{10}\right.$ molecules $\left.\mathrm{cm}^{-3}\right]$} & & & & \\
\hline 18.3.2003 & & 3,583 & 0,465 & 104,9 & 0,145 & 379,2 & 0,001 & 0,002 & 277,6 & 0,522 & 70,7 & 0,0017 \\
\hline 19.3.2003 & 0,803 & 1,832 & 0,285 & 112,1 & 0,060 & 391,5 & 0,479 & 1,219 & 276,6 & 0,584 & 52,0 & 0,0009 \\
\hline 20.3.2003 & 2,317 & 1,474 & 0,508 & 110,1 & 0,056 & 419,8 & 1,097 & 1,534 & 266,4 & 0,673 & 51,6 & 0,0009 \\
\hline 21.3.2003 & 4,169 & 5,350 & 1,207 & 108,8 & 0,757 & 416,6 & 0,001 & 0,002 & 269,5 & 0,817 & 42,9 & 0,0017 \\
\hline 22.3.2003 & 0,234 & 6,688 & 0,889 & 88,4 & 0,366 & 424,4 & 1,025 & 1,109 & 273,9 & 0,451 & 84,3 & 0,0071 \\
\hline 23.3.2003 & 2,340 & 2,910 & 0,484 & 108,6 & 0,063 & 373,8 & 0,738 & 1,118 & 279,6 & 0,766 & 65,4 & 0,0019 \\
\hline 24.3.2003 & & 1,840 & 0,320 & 113,9 & 0,053 & 354,0 & 0,592 & 1,012 & 278,9 & 0,637 & 58,2 & 0,0008 \\
\hline 25.3.2003 & 2,648 & 1,964 & 0,386 & 108,7 & 0,081 & 360,3 & 1,017 & 0,123 & 278,1 & 0,668 & 50,3 & 0,0009 \\
\hline 26.3.2003 & 4,941 & 10,999 & 2,238 & 100,6 & 1,529 & 384,4 & 1,304 & 1,546 & 279,2 & 0,686 & 54,7 & 0,0032 \\
\hline 27.3.2003 & & 7,107 & 1,562 & 127,2 & 0,286 & 470,4 & 0,792 & 1,398 & 279,7 & 0,740 & 63,9 & 0,0091 \\
\hline 28.3.2003 & 1,904 & 1,859 & 0,448 & 114,8 & 0,084 & 355,6 & 0,931 & 1,167 & 278,2 & 0,660 & 51,7 & 0,0009 \\
\hline 29.3.2003 & 2,655 & 5,022 & 0,584 & 108,9 & 0,351 & 372,9 & 0,001 & 0,002 & 278,3 & 0,498 & 50,0 & 0,0019 \\
\hline 30.3 .2003 & 0,148 & 6,425 & 0,622 & 116,3 & 0,048 & 562,1 & 0,445 & 1,003 & 276,2 & 0,215 & 90,6 & 0,0182 \\
\hline 31.3 .2003 & 2,147 & 1,674 & 0,851 & 102,0 & 0,069 & 418,6 & 0,441 & 1,298 & 268,1 & 0,504 & 62,7 & 0,0017 \\
\hline 1.4 .2003 & 3,311 & 3,651 & 0,643 & 96,2 & 0,514 & 417,3 & 0,951 & 1,500 & 269,7 & 0,678 & 45,2 & 0,0017 \\
\hline 2.4 .2003 & 3,928 & 3,371 & 2,850 & 100,0 & 0,251 & 431,5 & 1,416 & 1,629 & 270,7 & 0,457 & 43,6 & 0,0031 \\
\hline 3.4.2003 & 8,553 & 5,782 & 4,943 & 102,5 & 0,606 & 442,9 & 1,237 & 1,374 & 272,8 & 0,655 & 43,0 & 0,0039 \\
\hline 4.4.2003 & 2,638 & 4,040 & 0,764 & 96,6 & 0,307 & 402,9 & 0,961 & 0,983 & 273,4 & 0,471 & 61,2 & 0,0011 \\
\hline 5.4 .2003 & 0,423 & 2,018 & 0,434 & 99,1 & 0,078 & 409,3 & 0,497 & 1,534 & 271,7 & 0,284 & 92,9 & 0,0021 \\
\hline 6.4.2003 & 2,035 & 1,712 & 0,382 & 71,7 & 0,144 & 402,7 & 0,479 & 1,490 & 270,6 & 0,673 & 53,6 & 0,0012 \\
\hline 7.4.2003 & 6,107 & 1,699 & 1,365 & 97,7 & 0,125 & 379,8 & 0,694 & 1,465 & 271,5 & 0,734 & 44,8 & 0,0014 \\
\hline 8.4.2003 & 4,591 & 2,419 & 1,199 & 75,4 & 0,266 & 414,7 & 0,961 & 1,683 & 271,5 & 0,708 & 62,6 & 0,0019 \\
\hline Mean & 2,942 & 3,792 & 1,065 & 102,921 & 0,283 & 408,373 & 0,730 & 1,100 & 274,195 & 0,595 & 58,902 & 0,0031 \\
\hline
\end{tabular}

\subsection{Condensational sink}

The aerosol condensational sink (CS) determines how rapidly molecules will condense onto pre-existing aerosols (CS, Kulmala et al., 2001b) and can be calculated from

$C S=2 \pi D \int_{0}^{\infty} D_{p} \beta_{M}\left(D_{p}\right) n\left(D_{p}\right) d D_{p}=2 \pi D \int_{i} \beta_{M} D_{p_{i}} N_{i}$

$D$ is the diffusion coefficient of sulphuric acid and the transitional correction factor $\beta_{M}$ is typically calculated using the expression by Fuchs and Sutugin (1971). $N$ is the number concentration and $D_{p}$ is the diameter of the particles in the i'th size class measured with a DMPS (Differential mobility particle sizer) system at dry relative humidity (CS-1 in Fig. 1). The hygroscopic growth rate correction for particles measured in Hyytiälä at RH=90\% was included according to Hämeri et al. (2001) and further we used the growth parameterisation from Swietlicki et al. (2000) to count for the real relative humidity (CS-2 in Fig. 1). Finally, we also included particles larger than $500 \mathrm{~nm}$, measured with an APS (Aerodynamic Particle Sizer) system and handled them in the same way as the DMPS data explained above (CS-3 in Fig. 1).

\section{Observed data}

In this and the following sections, we concentrate our analysis on the days of the campaigns when sulphuric acid was measured (18 March until the 8 April). Figure 1 shows the different condensational sink values discussed in the previous section, as well as the wind direction. Figure 2 presents the concentrations of $\mathrm{NO}, \mathrm{NO}_{2}$ and $\mathrm{SO}_{2}$ and Fig. 3 gives the solar irradiance (UV-B: 280 to $320 \mathrm{~nm}$ ) and temperature profiles. Further, Table 1 gives the daytime averages (between 9 a.m. and 3 p.m.) of all these parameters including $\mathrm{H}_{2} \mathrm{SO}_{4}, \mathrm{O}_{3}, \mathrm{CO}, \mathrm{HCHO}$ (formaldehyde, 24-h averages), NMHC (non-methane hydrocarbon) and relative humidity for all days.

Over the whole period the average condensational sink calculated with the hygroscopicity and humidity parameterisations, explained in Sect. 2.5, were higher than those calculated from dry particle diameters by a factor of 1.35 (mean (CS-2)/mean (CS-1)). In addition, including the coarse mode particles, measured above $500 \mathrm{~nm}$, raised the condensation sink by a factor of 1.17 (mean (CS-3)/mean (CS-2)). Including all corrections for the CS values led to an overall increase of the condensational sink values calculated from the measured dry particle number concentrations and size distributions (DMPS-data: CS-1 in Fig. 1) to the estimated diameter of CS-3 by a factor of 1.58 .

The concentrations of $\mathrm{NO}$ and $\mathrm{NO}_{2}$ (Fig. 2 and Table 1) are in the range of BDL (below detection limit) to $1.1 \mathrm{ppb}$ (BDL $-2.9 \times 10^{10}$ molecules $\left.\mathrm{cm}^{-3}\right)$ and 0.45 to $8.3 \mathrm{ppb}\left(1.2 \times 10^{10}\right.$ $2.2 \times 10^{11}$ molecules $\left.\mathrm{cm}^{-3}\right)$, respectively. The concentration of $\mathrm{SO}_{2}$ was on the order of BDL to $4.6 \mathrm{ppb}$ (BDL $1.2 \times 10^{11}$ molecules $\mathrm{cm}^{-3}$ ). Low concentrations of all three gases ( $\mathrm{NO}$ and $\mathrm{SO}_{2}=\mathrm{BDL}$ and $\mathrm{NO}_{2}<1 \mathrm{ppb}$ ) were typical 


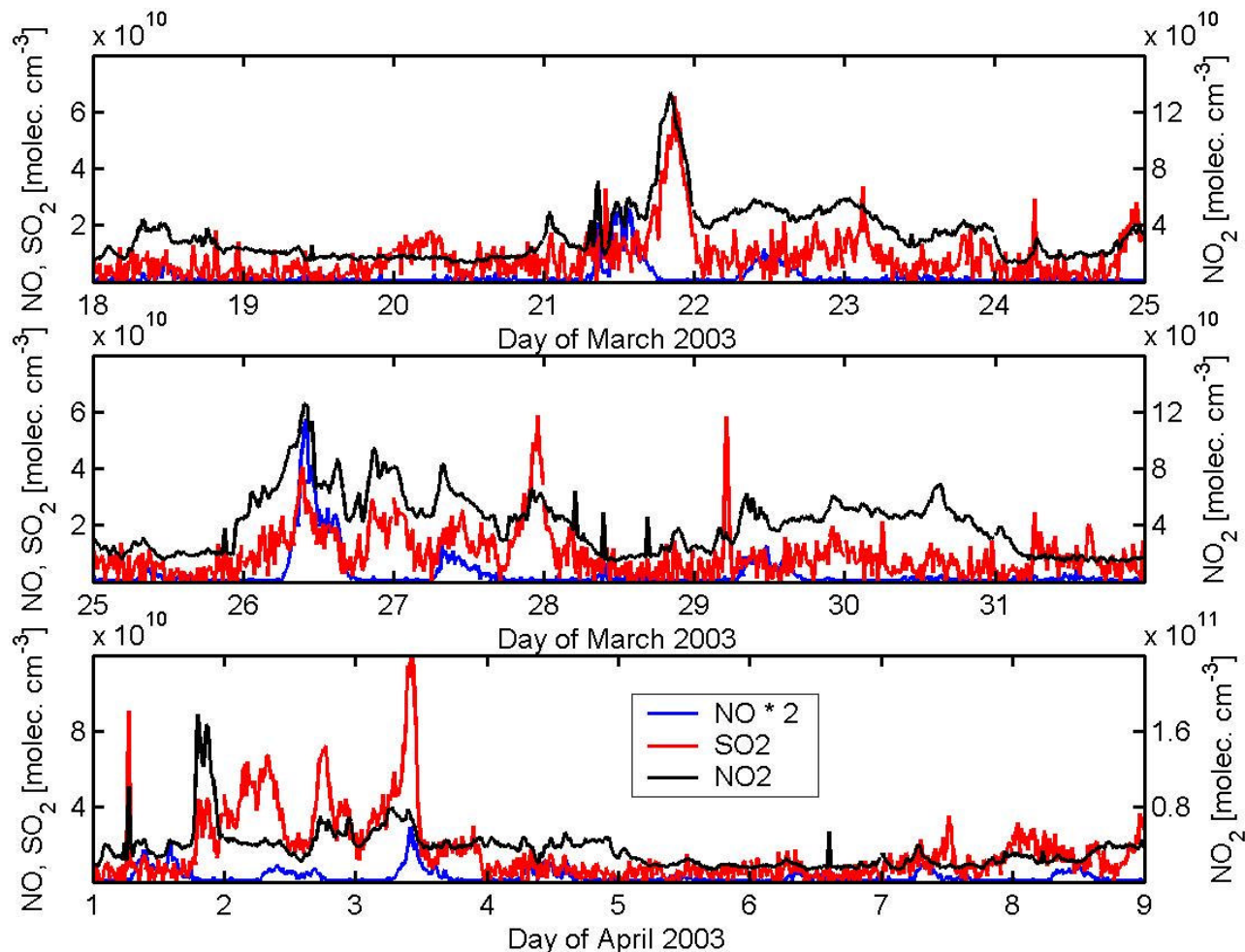

Fig. 2. Nitrogen oxide, nitrogen dioxide and sulphur dioxide concentrations for Hyytiälä, Finland.
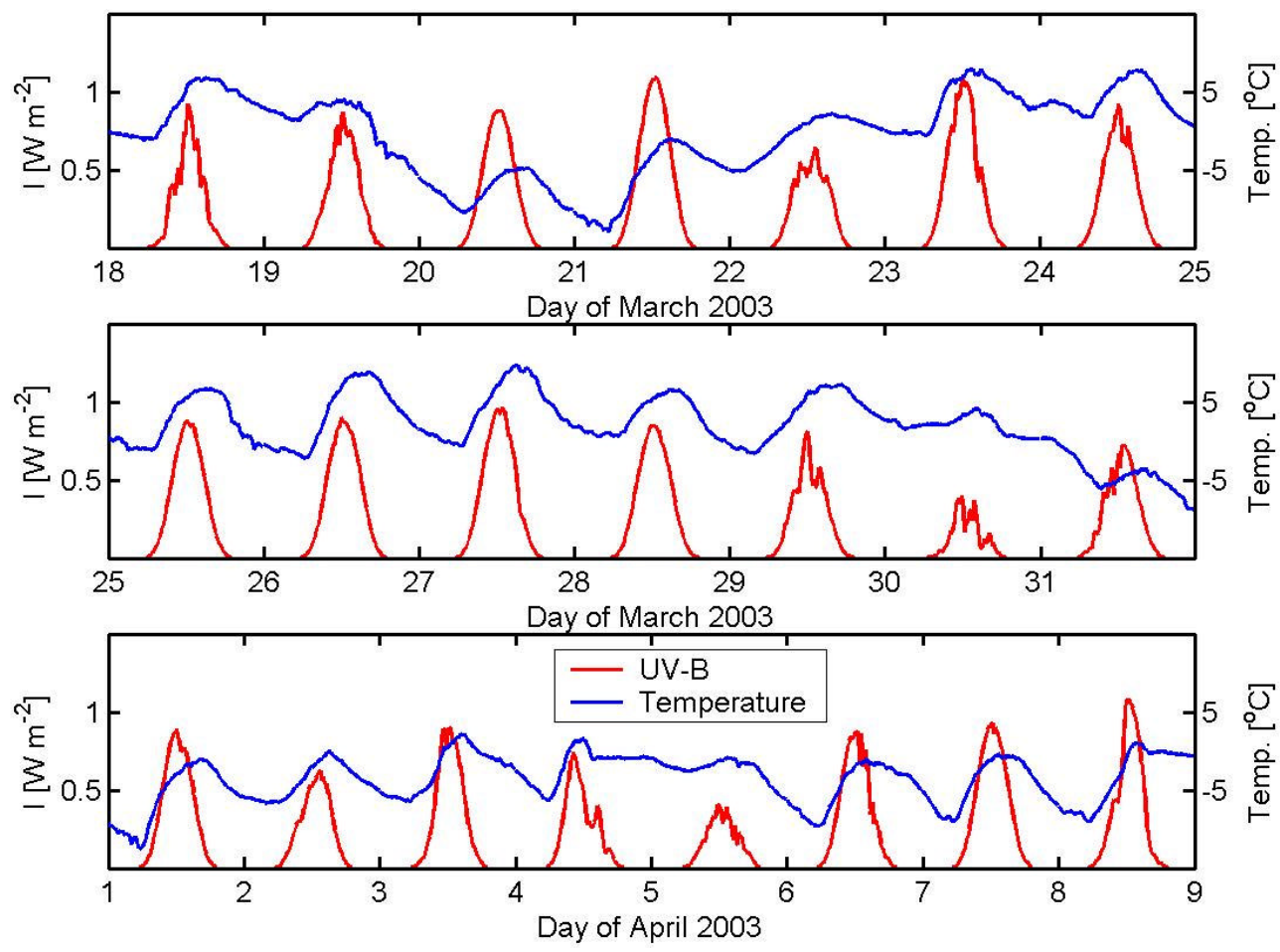

Fig. 3. Solar ultraviolet irradiance (280-320 nm) and temperature for Hyytiälä, Finland. 


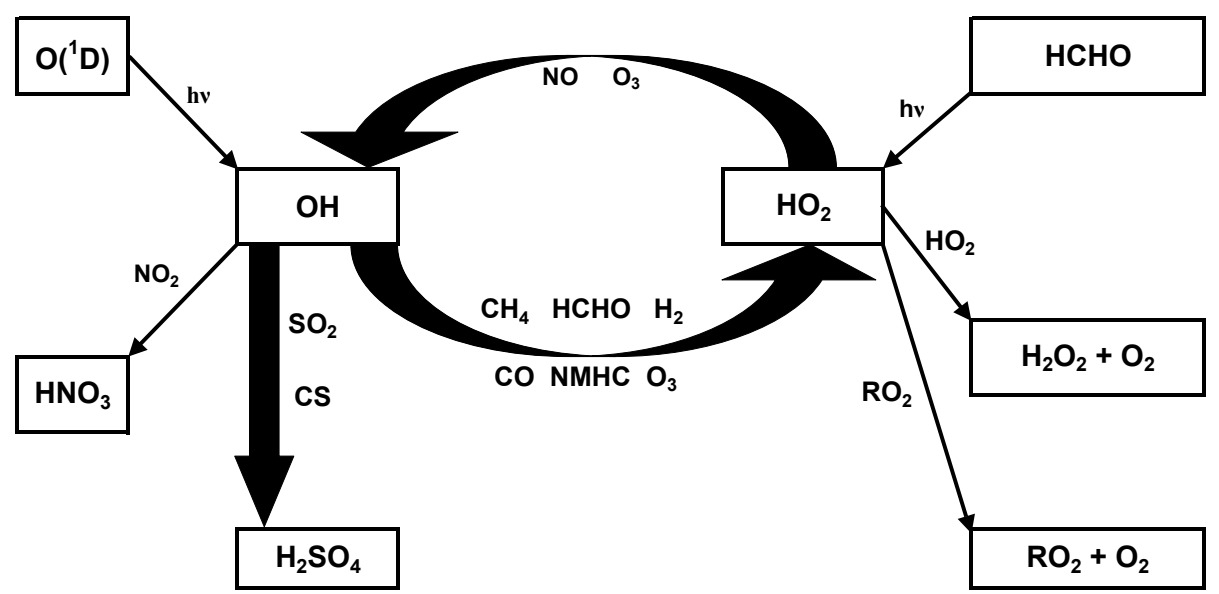

Fig. 4. Block diagram of the chemistry in the photo stationary state calculations.

during times, when less polluted air masses originated over the Northern Atlantic or the Polar region arrived at Hyytiälä. High CS-values are, in the majority of the days, accompanied by high concentrations of nitrogen oxide, nitrogen dioxide and sulphur dioxide. This rough classification agrees to a certain extent with the wind direction profile, which gives less polluted air masses during periods, when the wind direction was north-east to north-west.

The temperature profiles and the solar UV-B irradiance are plotted in Fig. 3. On the third day (20 March) the $\mathrm{T}_{\text {dav }}$ (daytime average temperature, see Table 1) dropped to $266.4 \mathrm{~K}$, the lowest value during the campaign. The wind direction during this day was close to North and signs indicate that Polar or Arctic air masses passed over the station. After this day, the $\mathrm{T}_{\mathrm{dav}}$ increased to $279.6 \mathrm{~K}$ and the wind direction changed to southeast. This resulted in an increase of NO, $\mathrm{NO}_{2}, \mathrm{SO}_{2}$ and $\mathrm{CS}$. Continuing in the same manner and including $72 \mathrm{~h}$ backward trajectories calculated by the HYSPLIT model (NOAA - National Oceanic and Atmospheric Administration, Rolph, 2003) we can clearly divide 16 days of the selected period into two categories:

- Less polluted air masses originated over the Atlantic or Polar region:

19, 20, 24, 25, 31 March, 5, 6 and 7 April.

- Higher polluted air masses passed over Central Europe or England:

21, 22, 26, 27, 29, 30 March, 2 and 3 April

We will apply this air mass classification in Sect. 5.4 to investigate the influence of different measured parameters on the radical balance and sulphuric acid concentration.

\section{Pseudo steady state model}

In order to calculate the concentrations of sulphuric acid we used a simple zero-dimensional box model (Fig. 4). The intention was not to run a full-scale model with the complete organic and inorganic chemistry, but rather to check the consistency of our model with measured sulphuric acid concentration values. With the limited number of compounds measured in the present study, a full model including biogenic VOC chemistry would result in substantial uncertainties with respect to the calculated concentrations. Photo stationary state conditions were assumed for each of the radical species, i.e. both $\mathrm{OH}$ and $\mathrm{HO}_{2}$ were assumed sufficiently short-lived that they remain in steady state with the ambient conditions. The model can be called as pseudo steady state model (see Seinfeld and Pandis, 1998). This gives us the balance equations for the radicals:

$\frac{d[\mathrm{C}]}{\mathrm{dt}} \approx 0=\mathrm{P}_{C}-\mathrm{L}_{C}$.

Here $\mathrm{P}_{C}$ represents the total production rate for $\mathrm{C}$, and $\mathrm{L}_{C}$ is the corresponding loss rate. The balance equations for both radicals can now be solved by using the measured concentrations of the other species as input parameters. We used a typically northern hemisphere value of $500 \mathrm{ppb}$ for $\mathrm{H}_{2}$ and for methane an average value of $1.941 \mathrm{ppm}$ (see Sect. 2.3). The $\left[\mathrm{HO}_{2}\right] /\left(\left[\mathrm{HO}_{2}\right]+\Sigma\left[\mathrm{RO}_{2}\right]\right)$ ratio is typically 0.5-0.8 (Cantrell et al., 1996, 1997). Recent studies by Carslaw et al. (2002) during the Eastern Atlantic Spring Experiment 1997 (EASE97) at Mace Head, Ireland measured lower values of $0.18-0.4$. In our analysis, we decided to use a mean value from the published data, which is 0.5 and gives $\left[\mathrm{HO}_{2}\right]=\left[\mathrm{RO}_{2}\right]$. However, in sensitivity studies in Sect. $5.2 \mathrm{we}$ will change this parameter to investigate its influence on the radical budgets. All reactions and rate coefficients included in the radical balance calculations and the calculation for sulphuric acid concentration are listed in Table 2.

The used balance equation for calculating the $\mathrm{OH}$ radical concentrations with the $\mathrm{k}$-values from Table 2 is

$$
\begin{aligned}
\mathrm{OH} & =\frac{\mathrm{P}_{\mathrm{OH}}}{\mathrm{L}_{\mathrm{OH}}} \\
\mathrm{P}_{\mathrm{OH}} & =2 *\left[\mathrm{O}_{3}\right] * \mathrm{jO}_{3} *\left[\mathrm{H}_{2} \mathrm{O}\right] * \mathrm{k}_{1}+\left[\mathrm{HO}_{2}\right] *[\mathrm{NO}] * \mathrm{k}_{2}+ \\
& {\left[\mathrm{HO}_{2}\right] *\left[\mathrm{O}_{3}\right] * \mathrm{k}_{3} }
\end{aligned}
$$


Table 2. Reactions and rate coefficients used in the photo stationary calculations of the radical concentrations. All rate coefficients have been calculated for a relevant average temperature of $273 \mathrm{~K}$ using the temperature dependent rate equations from Atkinson et al. (2001) and Seinfeld and Pandis (1998).

\begin{tabular}{|c|c|c|c|c|c|c|c|}
\hline Nr. & \multicolumn{5}{|c|}{ Reactions } & \multicolumn{2}{|c|}{$\begin{array}{c}j \text { and } k \text { at } 273 \mathrm{~K} \text { and } 1 \mathrm{bar} \\
\mathrm{k} \text { in }\left[\mathrm{cm}^{3} \text { molecule }^{-1} \mathrm{~s}^{-1}\right] \\
\mathrm{j} \text { in }\left[\mathrm{s}^{-1}\right]\end{array}$} \\
\hline 1. & $\begin{array}{l}\text { OH pro } \\
\mathrm{O}_{3} \\
\mathrm{O}\left({ }^{1} \mathrm{D}\right)\end{array}$ & $\begin{array}{l}\text { duction tern } \\
+\quad \mathrm{hv} \\
+\quad \mathrm{H}_{2} \mathrm{O}\end{array}$ & $\begin{array}{l}\text { ns } \\
\longrightarrow \\
\longrightarrow 2\left({ }^{1} \mathrm{D}\right) \\
\longrightarrow 2 \mathrm{OH}\end{array}$ & $\mathrm{O}_{2}$ & & $\begin{array}{l}\mathrm{j}_{\mathrm{O} 3} \\
\mathrm{k}_{1}\end{array}$ & $\begin{array}{c}\text { Max. }=1.22 * 10^{-5} \\
2,2 * 10^{-10}\end{array}$ \\
\hline 3. & $\begin{array}{l}\mathrm{OH} \text { pro } \\
\mathrm{HO}_{2} \\
\mathrm{HO}_{2} \\
\end{array}$ & $\begin{array}{l}\text { duction and } \\
+\quad \mathrm{NO} \\
+\quad \mathrm{O}_{3} \\
\end{array}$ & $\begin{array}{l}\mathrm{HO}_{2} \text { loss terms } \\
\longrightarrow \mathrm{OH} \\
\longrightarrow \mathrm{OH}\end{array}$ & $\begin{array}{r}\mathrm{NO}_{2} \\
+\quad 2 \mathrm{O}_{2} \\
\end{array}$ & & $\begin{array}{l}k_{2} \\
k_{3}\end{array}$ & $\begin{array}{l}9,24 * 10^{-12} \\
1,76 * 10^{-15} \\
\end{array}$ \\
\hline 5. & $\begin{array}{l}\mathrm{OH} \text { los } \\
\mathrm{OH} \\
\mathrm{OH}\end{array}$ & $\begin{array}{l}\text { terms } \\
+\quad \mathrm{NO}_{2} \\
+\quad \mathrm{CH}_{4}\end{array}$ & $\begin{array}{ll}\longrightarrow & \mathrm{M} \\
\longrightarrow & \mathrm{HNO}_{3} \\
\longrightarrow & \mathrm{CH}_{3}\end{array}$ & $+\mathrm{H}_{2} \mathrm{O}$ & & $\begin{array}{l}k_{4} \\
k_{5}\end{array}$ & $\begin{array}{l}1,41 * 10^{-11} \\
3,55 * 10^{-15}\end{array}$ \\
\hline $\begin{array}{l}7 . \\
8 . \\
9 .\end{array}$ & $\begin{array}{l}\mathrm{OH} \text { los } \\
\mathrm{OH} \\
\mathrm{OH} \\
\mathrm{OH} \\
\mathrm{OH} \\
\mathrm{OH}\end{array}$ & $\begin{array}{l}\text { and } \mathbf{H O}_{2} \mathbf{p} \\
+\quad \mathrm{CO} \\
+\quad \mathrm{HCHO} \\
+\quad \mathrm{H}_{2} \\
+\quad \mathrm{O}_{3} \\
+\quad \mathrm{NMHC}\end{array}$ & $\begin{array}{ll}\text { roduction terms } \\
\stackrel{\mathrm{O}_{2}}{\longrightarrow} & \mathrm{HO}_{2} \\
\stackrel{\mathrm{O}_{2}}{\longrightarrow} & \mathrm{HO}_{2} \\
& \mathrm{HO}_{2} \\
\stackrel{\mathrm{OO}_{2}}{\longrightarrow} & \mathrm{HO}_{2}\end{array}$ & $\begin{array}{cc}+ & \mathrm{CO}_{2} \\
+ & \mathrm{CO} \\
+ & \mathrm{H}_{2} \mathrm{O} \\
+ & \mathrm{O}_{2} \\
+ & \mathrm{H}_{2} \mathrm{O}\end{array}$ & $+\mathrm{H}_{2} \mathrm{O}$ & $\begin{array}{l}\mathrm{k}_{6} \\
\mathrm{k}_{7} \\
\mathrm{k}_{8} \\
\mathrm{k}_{9} \\
\mathrm{k}_{10}\end{array}$ & $\begin{array}{c}1,50 * 10^{-13} \\
9,37 * 10^{-12} \\
3,53 * 10^{-15} \\
5,12 * 10^{-14} \\
\text { various }\end{array}$ \\
\hline 11. & $\begin{array}{l}\mathbf{H O}_{2} \mathbf{p r} \\
\mathrm{HCHO}\end{array}$ & \multicolumn{3}{|c|}{$\mathrm{HO}_{2}$ production terms } & & $\mathrm{j}_{\mathrm{HCHO}}$ & Max. $=1.23 * 10^{-5}$ \\
\hline 12. & $\begin{array}{c}\mathrm{HO}_{2} \mathrm{los} \\
\mathrm{HO}_{2} \\
\mathrm{HO}_{2}\end{array}$ & $\begin{array}{l}\text { s terms } \\
+\quad \mathrm{HO}_{2} \\
+\quad \mathrm{RO}_{2}\end{array}$ & $\begin{array}{ll}\longrightarrow & \mathrm{H}_{2} \mathrm{O}_{2} \\
\longrightarrow & \mathrm{ROOH}\end{array}$ & $\begin{array}{l}+\mathrm{O}_{2} \\
+\quad \mathrm{O}_{2}\end{array}$ & & $\begin{array}{l}k_{12} \\
k_{13}\end{array}$ & $\begin{array}{c}5,33 * 10^{-12} \\
1,6 * 10^{-11}\end{array}$ \\
\hline 14. & $\begin{array}{c}\mathrm{H}_{2} \mathrm{SO}_{4} \\
\mathrm{OH}\end{array}$ & $\begin{array}{l}\text { production } \mathrm{t} \\
+\quad \mathrm{SO}_{2}\end{array}$ & $\begin{array}{l}\text { erms and } \mathrm{OH} \text { los } \\
\longrightarrow \mathrm{H}_{2} \mathrm{SO}_{4}\end{array}$ & s term & & $\mathrm{k}_{14}$ & $9,82 * 10^{-13}$ \\
\hline
\end{tabular}

$$
\begin{gathered}
\mathrm{L}_{\mathrm{OH}}=\left[\mathrm{NO}_{2}\right] * \mathrm{k}_{4}+\left[\mathrm{CH}_{4}\right] * \mathrm{k}_{5}+[\mathrm{CO}] * \mathrm{k}_{6}+ \\
{[\mathrm{HCHO}] * \mathrm{k}_{7}+\left[\mathrm{H}_{2}\right] * \mathrm{k}_{8}+\left[\mathrm{O}_{3}\right] * \mathrm{k}_{9}+} \\
{[\mathrm{NMHC}] * \mathrm{k}_{10}+\left[\mathrm{SO}_{2}\right] * \mathrm{k}_{14}}
\end{gathered}
$$

In the same way, the $\mathrm{HO}_{2}$ radical concentrations were determined. In order to solve the two coupled equations we used for each time step 10 iterations. With the achieved hydroxyl concentrations and the CS-values we further estimated the concentrations of sulphuric acid.

The photolysis rates ( $\mathrm{jo3}_{3}$ ) for ozone were calculated by using spectral irradiance data measured by a radiospectrometer. A detailed description of the theory and the instrument is given in Boy and Kulmala (2002a). In the same way, we calculated the photolysis rate for formaldehyde by using the absorption cross sections and quantum yields from DeMore et al. (1994). Concerning the uncertainties of the photolysis rates, it is worth to mention that the radio-spectrometer is placed about $0.5 \mathrm{~km}$ away from the measuring station SMEAR II. During periods with high frac- tion of cumulus clouds, this could result in significant temporal differences in measured and photochemical active radiation at the station.

\section{Results and discussion}

The results were divided into four parts. In the first section, we will discuss the calculation of the hydroxyl and hydroperoxy radicals and the fraction of the sinks and sources of these species. The next sub-section will give a comparison between the measured and calculated sulphuric acid concentrations and show the closure. Also sensitivity studies of the influence of some key parameters were performed. In the following sub-section we determine the contribution of the sulphuric acid molecules to the particle growth rates. In the end of this section, we use the air mass classification given in Sect. 3 and point out the differences of some variables. 

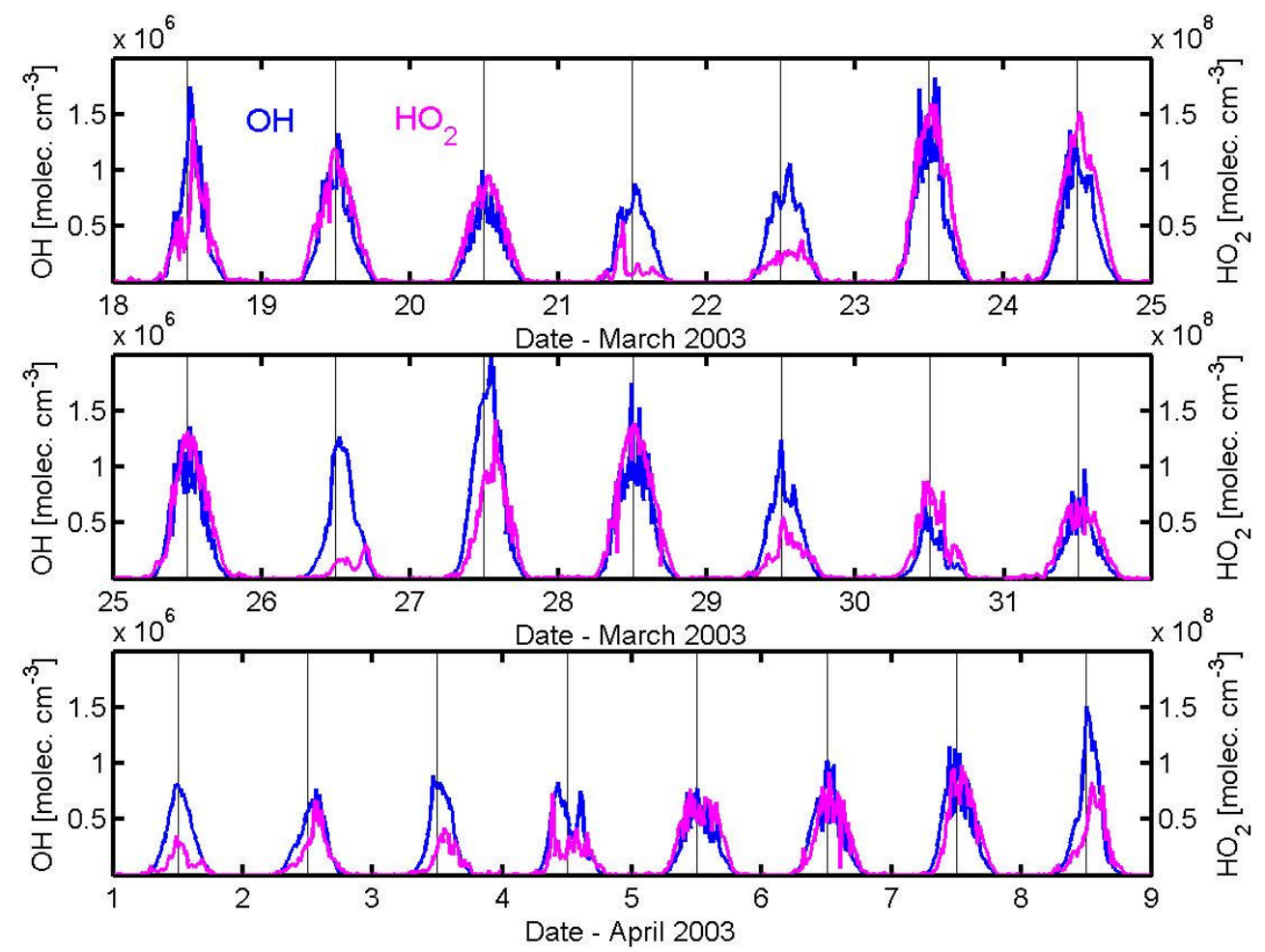

Fig. 5. Calculated hydroxyl and hydroperoxy radical concentrations for Hyytiälä, Finland.

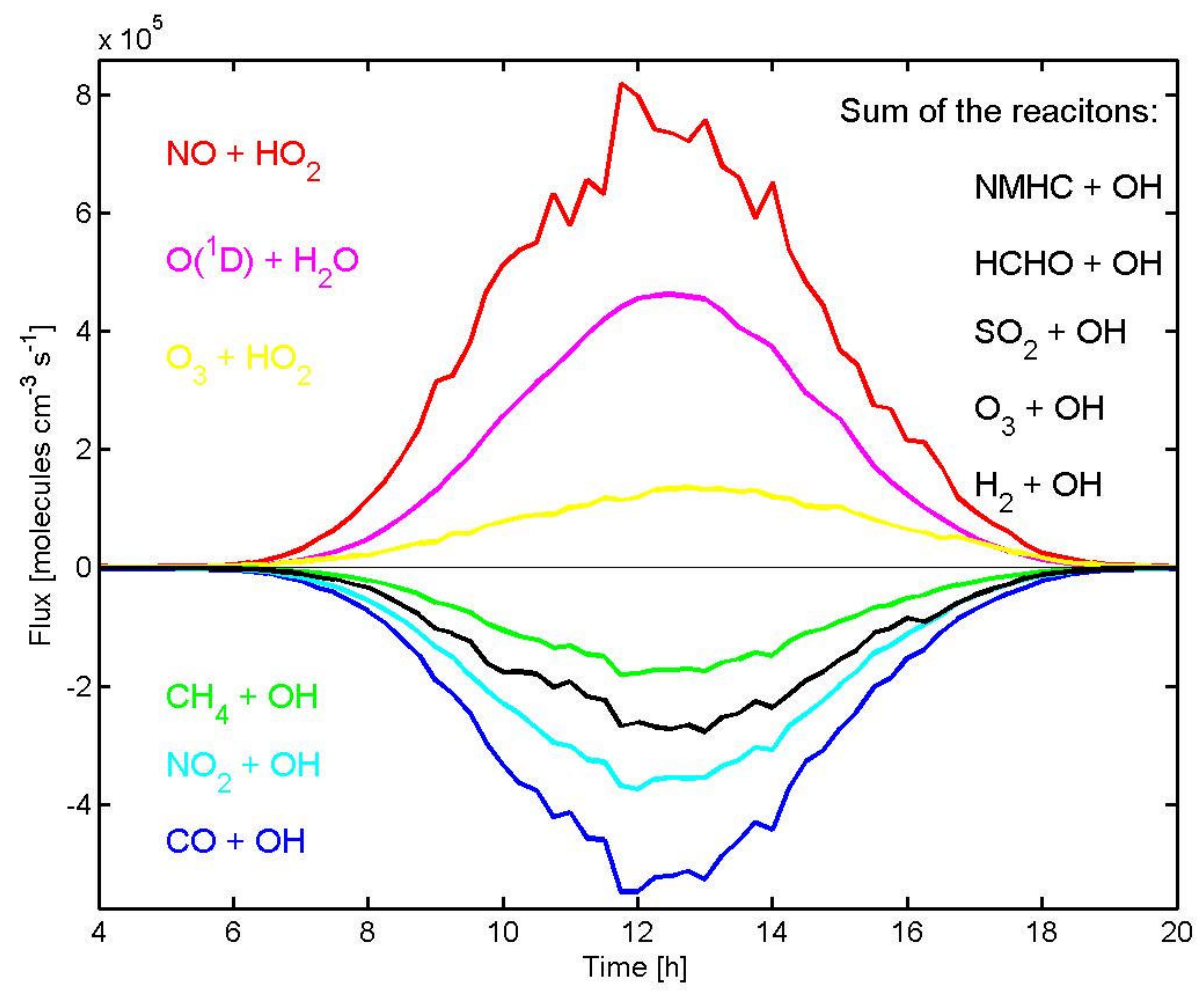

Fig. 6. Plot of calculated contributions of various sink and source terms for the hydroxyl radical concentration averaged for 15-min time intervals between the 18 March and the 8 April 2003 . 
Table 3. Average sink and source terms of the $\mathrm{OH}$ and $\mathrm{HO}_{2}$ radical balance for the 18 March until the 8 April 2003 (Mean $\mathrm{I}=\mathrm{average}$ for all days between 8 a.m. and 4 p.m.; Mean $\mathrm{II}=$ average daily maxims with $\mathrm{H}$ and $\mathrm{L}$ are the highest and lowest values; Mean $\mathrm{III}=\mathrm{average}$ contributions of the single reactions to the corresponding source and loss terms of one radical with $\mathrm{H}$ and $\mathrm{L}$ are the highest and lowest values).

\begin{tabular}{|c|c|c|c|c|c|c|c|}
\hline & $\begin{array}{c}\text { Mean I } \\
{\left[10^{6} \text { molec. } \mathrm{cm}^{-3} \mathrm{~s}^{-1}\right]}\end{array}$ & $\begin{array}{r}\text { Mean II } \\
{[1}\end{array}$ & $\begin{array}{l}\mathrm{H} \text { Mean } \\
\text { nolec. } \mathrm{Cr}\end{array}$ & $\begin{array}{l}\text { L Mean II } \\
\left.-{ }^{-1}\right]\end{array}$ & Mean III & $\begin{array}{c}\text { H Mean II } \\
{[\%]}\end{array}$ & L Mean III \\
\hline \multicolumn{8}{|l|}{ OH-Sources } \\
\hline $\mathrm{NO}+\mathrm{HO}_{2}$ & 0,443 & 1,010 & 1,618 & 0,437 & 55,9 & 73,4 & 33,4 \\
\hline $\mathrm{O}\left({ }^{1} \mathrm{D}\right)+\mathrm{H}_{2} \mathrm{O}$ & 0,279 & 0,496 & 1,151 & 0,211 & 33,4 & 48,7 & 20,0 \\
\hline $\mathrm{O}_{3}+\mathrm{HO}_{2}$ & 0,085 & 0,166 & 0,320 & 0,023 & 10,6 & 20,1 & 1,0 \\
\hline \multicolumn{8}{|l|}{ OH-Sinks } \\
\hline $\mathrm{CO}+\mathrm{OH}$ & $-0,322$ & $-0,653$ & $-0,384$ & $-1,074$ & 41,0 & 52,4 & 23,1 \\
\hline $\mathrm{NO}_{2}+\mathrm{OH}$ & $-0,241$ & $-0,444$ & $-0,209$ & $-1,145$ & 29,7 & 52,8 & 18,3 \\
\hline $\mathrm{CH}_{4}+\mathrm{OH}$ & $-0,104$ & $-0,215$ & $-0,089$ & $-0,408$ & 12,9 & 16,5 & 8,8 \\
\hline $\mathrm{NMHC}+\mathrm{OH}$ & $-0,034$ & $-0,078$ & $-0,004$ & $-0,201$ & 3,9 & 9,1 & 0,3 \\
\hline $\mathrm{HCHO}+\mathrm{OH}$ & $-0,041$ & $-0,083$ & $-0,019$ & $-0,158$ & 5,1 & 8,5 & 1,9 \\
\hline $\mathrm{O}_{3}+\mathrm{OH}$ & $-0,030$ & $-0,062$ & $-0,029$ & $-0,118$ & 3,7 & 5,0 & 2,4 \\
\hline $\mathrm{H}_{2}+\mathrm{OH}$ & $-0,026$ & $-0,054$ & $-0,023$ & $-0,106$ & 3,2 & 4,2 & 2,3 \\
\hline $\mathrm{SO}_{2}+\mathrm{OH}$ & $-0,004$ & $-0,013$ & $-0,004$ & $-0,033$ & 0,6 & 1,6 & 0,2 \\
\hline \multicolumn{8}{|l|}{$\mathrm{HO}_{2}$-Sources } \\
\hline $\mathrm{CO}+\mathrm{OH}$ & 0,322 & 0,653 & 1,074 & 0,384 & 53,8 & 63,7 & 41,9 \\
\hline $\mathrm{CH}_{4}+\mathrm{OH}$ & 0,104 & 0,215 & 0,408 & 0,089 & 16,9 & 21,2 & 13,7 \\
\hline $\mathrm{HCHO}+\mathrm{h} v$ & 0,048 & 0,074 & 0,123 & 0,020 & 8,4 & 16,1 & 2,5 \\
\hline $\mathrm{NMHC}+\mathrm{OH}$ & 0,034 & 0,078 & 0,201 & 0,004 & 5,1 & 10,8 & 0,5 \\
\hline $\mathrm{HCHO}+\mathrm{OH}$ & 0,041 & 0,083 & 0,158 & 0,019 & 6,7 & 10,3 & 3,2 \\
\hline $\mathrm{O}_{3}+\mathrm{OH}$ & 0,030 & 0,062 & 0,118 & 0,029 & 4,8 & 6,1 & 3,4 \\
\hline $\mathrm{H}_{2}+\mathrm{OH}$ & 0,026 & 0,054 & 0,106 & 0,023 & 4,3 & 5,4 & 3,4 \\
\hline \multicolumn{8}{|l|}{$\mathrm{HO}_{2}-$ Sinks } \\
\hline $\mathrm{NO}+\mathrm{HO}_{2}$ & $-0,443$ & $-1,009$ & $-0,437$ & $-1,625$ & 75,7 & 98,0 & 49,9 \\
\hline $\mathrm{O}_{3}+\mathrm{HO}_{2}$ & $-0,085$ & $-0,166$ & $-0,023$ & $-0,320$ & 13,9 & 29,8 & 1,9 \\
\hline $\mathrm{RO}_{2}+\mathrm{HO}_{2}$ & $-0,053$ & $-0,144$ & $-0,002$ & $-0,390$ & 8,0 & 19,7 & 0,1 \\
\hline $\mathrm{HO}_{2}+\mathrm{HO}_{2}$ & $-0,017$ & $-0,045$ & $-0,001$ & $-0,126$ & 2,5 & 6,2 & 0,0 \\
\hline
\end{tabular}

\section{$5.1 \mathrm{OH}$ and $\mathrm{HO}_{2}$ concentrations}

Figure 5 gives the calculated hydroxyl and hydroperoxy radical concentrations for the selected period. The daily maxima for the $\mathrm{OH}$ and the $\mathrm{HO}_{2}$ species are in the range of $4.1 \times 10^{5}$ to $1.8 \times 10^{6}$ molecules $\mathrm{cm}^{-3}$ and $1.0 \times 10^{7}$ to $1.5 \times 10^{8}$ molecules $\mathrm{cm}^{-3}$, respectively. The calculated values are in agreement with earlier model calculations for the same site (SMEAR II) by Hakola et al. (2003). Figures 6 and 7 show the diurnal contributions of the different sink and source terms for both radicals, averaged for the selected days and Table 3 gives some statistical parameters concerning these calculations. The nomenclature of sink and source terms in this context is somehow controversial, although often used in the literature. However, during this work we will retain the terms and point out that different opinions concerning the use of sink and source terms in this context exist.

Concerning the daytime averages of the whole period more than $55 \%$ of the $\mathrm{OH}$ production results from the reaction of hydroperoxy radicals with nitrogen oxide and around one third is produced by the photolysis of ozone and the following reaction of the exited oxygen molecules with water vapour. The reaction of ozone with $\mathrm{HO}_{2}$ contributes only $10 \%$ to the $\mathrm{OH}$ concentration. However, during single days like for example the 23 March with high values of solar irradiance (see Fig. 3) and low concentrations of NO (see Fig. 2) the photolysis of ozone contributes close to half of the hydroxyl radical concentration. During the 21 days, the Reactions 1 to 3 of Table 2 participate in the $\mathrm{OH}$-formation with $20-49 \%, 33-73 \%$ and $1-20 \%$, respectively.

For the various sink terms of the $\mathrm{OH}$ radicals (Reactions 4-10 and 14 of Table 2) the dominating ones with over $83 \%$ concerning the daytime averages are the three reaction of $\mathrm{OH}$ radicals with $\mathrm{CO}(\approx 41 \%), \mathrm{NO}_{2}(\approx 30 \%)$ and $\mathrm{CH}_{4}(\approx 13 \%)$. All the other reactions contribute together less than $17 \%$ to the decrease of the hydroxyl concentration. Worth mentioning is that the reaction of the non-methane hydrocarbons with the $\mathrm{OH}$ radicals can reach up to $9.1 \%$ on single days. However, comparing this result with earlier publications (Carslaw et al., 2002 and Handisides et al., 2003) the fraction of the $\mathrm{NMHC}$ in the $\mathrm{OH}-$ balance in our calculations is low. The reason for underestimating the influence of the NMHC comes from the fact, that monoterpenens and formaldehyde were the only non-methane hydrocarbons measured during the QUEST campaign. We will consider this in the next subsection and use different values for the NMHCs in sensitivity studies. 
Table 4. Sensitivity study of the calculated sulphuric acid concentrations in comparison with the measured ones (M-Ratio=Mean value of the daily ( 9 a.m. -3 p.m.) averaged ratios between measurements and calculations, S-Ratio=standard deviation of these values and GAP=the difference in percent between measured and calculated concentrations). Highlighted fields are the parameters changed for investigation.

\begin{tabular}{|c|c|c|c|c|c|c|}
\hline Scenario & $\mathrm{NMHC}$ & $\mathrm{RO}_{2}$ & $\mathrm{NO}_{2}$ & M-Ratio & S-Ratio & GAP \\
\hline $\mathrm{SC}-1$ & $\mathrm{M}$ & $=[\mathrm{HO} 2]$ & $\mathrm{M}$ & 1.16 & 0.636 & 16 \\
\hline $\mathrm{SC}-2$ & $2{ }^{*} \mathrm{M}$ & $=[\mathrm{HO} 2]$ & $\mathrm{M}$ & 1.17 & 0.635 & 17 \\
$\mathrm{SC}-3$ & $4{ }^{*} \mathrm{M}$ & $=[\mathrm{HO} 2]$ & $\mathrm{M}$ & 1.19 & 0.635 & 19 \\
\hline $\mathrm{SC}-4 \mathrm{a}$ & $\mathrm{M}$ & $=0,25{ }^{*}[\mathrm{HO} 2]$ & $\mathrm{M}$ & 1.10 & 0.645 & 10 \\
$\mathrm{SC}-4 \mathrm{~b}$ & $\mathrm{M}$ & $=0,5^{*}[\mathrm{HO} 2]$ & $\mathrm{M}$ & 1.12 & 0.641 & 12 \\
$\mathrm{SC}-5 \mathrm{a}$ & $\mathrm{M}$ & $=2{ }^{*}[\mathrm{HO} 2]$ & $\mathrm{M}$ & 1.22 & 0.623 & 22 \\
$\mathrm{SC}-5 \mathrm{~b}$ & $\mathrm{M}$ & $=4{ }^{*}[\mathrm{HO} 2]$ & $\mathrm{M}$ & 1.27 & 0.631 & 27 \\
\hline $\mathrm{SC}-6$ & $\mathrm{M}$ & $=[\mathrm{HO} 2]$ & $\mathrm{NO}_{2}-\mathrm{SC} \mathrm{I}$ & 1.07 & 0.522 & 7 \\
$\mathrm{SC}-7$ & $\mathrm{M}$ & $=[\mathrm{HO} 2]$ & $\mathrm{NO}_{2}-\mathrm{SC} \mathrm{II}$ & 0.98 & 0.412 & -2 \\
\hline $\mathrm{SC}-8$ & $2{ }^{*} \mathrm{M}$ & $=[\mathrm{HO} 2]$ & $\mathrm{NO}^{2}-\mathrm{SC} \mathrm{II}$ & 0.99 & 0.412 & -1 \\
\hline
\end{tabular}

In the same way as above we calculated the contributions of the single reactions to the production (Reactions 6-11 Table 2) and loss (Reactions 2, 3, 12 and 13 of Table 2) of the hydroperoxy radicals. The $\mathrm{HO}_{2}$ production comes in average with more than $53 \%$ through the reaction of $\mathrm{OH}$ with $\mathrm{CO}$. All other reactions play a minor role here, contributing between 4 to $17 \%$. The loss terms for this radical are even more strongly dominated by one term, which is the reaction of $\mathrm{NO}$ with $\mathrm{HO}_{2}$ (average=75\%). During single days, this term contributes up to $98 \%$ to the decrease of the hydroperoxy concentrations.

\section{$5.2 \quad \mathrm{H}_{2} \mathrm{SO}_{4}$ concentrations}

In this section, we calculate sulphuric acid concentrations using the condensational sink values (see Sect. 2) and perform sensitivity studies for several parameters to investigate the influence of certain variables. Table 4 gives the selected values for three different variables (NMHC, $\mathrm{RO}_{2}$ and $\mathrm{NO}_{2}$ ) and the means and standard deviations of the ratios ( 9 a.m. to 3 p.m.) between measured and calculated sulphuric acid concentrations. We also investigate the closure between measured and calculated values. The overall goal of these sensitivity studies are not to modify data to reach the best fit with the measured sulphuric acid concentration, but to investigate the possible uncertainties and the resulting effects of different relevant parameters.

The concentrations of the non-methane hydrocarbons consist in this work only of measurements from monoterpenes.
Isoprene and other NMHC's were not measured during the campaign. However, from exploratory measurements made at Hyytiälä in April, 1999 (Janson, unpublished data) as well as from EMEP VOC data (e.g. EMEP/CCC Report 7/2001), we would expect reactive alkene concentrations, such as ethene, propene, and butene, to be on the order of tens to hundreds of ppts, and less reactive aromatics, like benzene and toluene, to be a few hundred ppts and tens to a hundred ppts, respectively, depending greatly on the air mass trajectory. The natural sources for isoprene, in the Nordic countries, are Norway spruce and Sphagnum moss in wetlands. However, the emission of isoprene from these sources, especially from wetlands, should be very low at this time of year (Janson and De Serves, 1998). Therefore, we would expect our NMHC concentrations to be on the order of a factor 2 too low. We used twice and four times higher values from the monoterpenes to investigate the behaviour of different NMHC-values on the OH-budget and so on the sulphuric acid concentration. The results presented in Table 4 under scenario 1 (SC-1) indicate that the mean measured sulphuric acid concentrations are $16 \%$ higher than the calculated ones. Increasing the concentrations of the non-methane hydrocarbons by factors of 2 and 4 (SC-2 and SC-3, Table 4) increased the gap between measured and calculated $\mathrm{H}_{2} \mathrm{SO}_{4}$ concentrations from 16 to 17 and $19 \%$, respectively (=decrease of our calculated $\mathrm{H}_{2} \mathrm{SO}_{4}$ concentrations compared to measured ones by 1 and 3\%). The reason is simple to understand. A larger NMHC load increases the competition for the $\mathrm{OH}$ radical and thereby decreases the rate of reaction for $\mathrm{SO}_{2}$.

Peroxy radicals are the sum of $\mathrm{HO}_{2}$ and $\mathrm{RO}_{2}$. The concentrations of the first one were calculated using our model (see Sect. 3). The relation of $\mathrm{RO}_{2}$ to $\mathrm{HO}_{2}$ was discussed in Sect. 4 and now we used different values for this ratio. Using half or quarter values of $\mathrm{RO}_{2}$ compared to $\mathrm{HO}_{2}$ increased the calculated sulphuric acid concentrations by 4 and $6 \%$, respectively (SC 4a and b, Table 4). A decline of 6 and $11 \%$ was achieved by doubling and quadrupling the fraction of $\mathrm{RO}_{2}$ compared to $\mathrm{HO}_{2}$ (SC 5a and b, Table 4). The peroxy radical contributes on single days up to $20 \%$ to the sink terms of the hydroperoxy radicals and decreases thereby significantly the sources for $\mathrm{OH}$. However, the $\mathrm{RO}_{2}$ concentrations are maybe overestimated since the reaction of this radical with $\mathrm{NO}$ is neglected and its reaction rates can be much higher than the $\mathrm{HO}_{2}-\mathrm{RO}_{2}$ rates under certain conditions, which leads to an important decrease of the $\mathrm{RO}_{2}$ concentrations. For this reason we will use the ratio of $\left[\mathrm{HO}_{2}\right]=\left[\mathrm{RO}_{2}\right]$ during the rest of this manuscript.

As a last variable we investigated the effect of $\mathrm{NO}_{2}$ concentration. The chemiluminescence analyzer used for detecting $\mathrm{NO}$ and $\mathrm{NO}_{\mathrm{x}}$ was not $\mathrm{NO}_{2}$ specific. Its catalytic converter used to measure $\mathrm{NO}_{2}$ after reduction to $\mathrm{NO}$ reduces also other oxidized nitrogen species. Therefore the $\mathrm{NO}_{2}$ concentration readings (obtained as the calculated difference between the measured $\mathrm{NO}$ and $\mathrm{NO}_{\mathrm{x}}$ concentrations) may have interference of $\mathrm{HONO}, \mathrm{HNO}_{3}$, PAN and other 


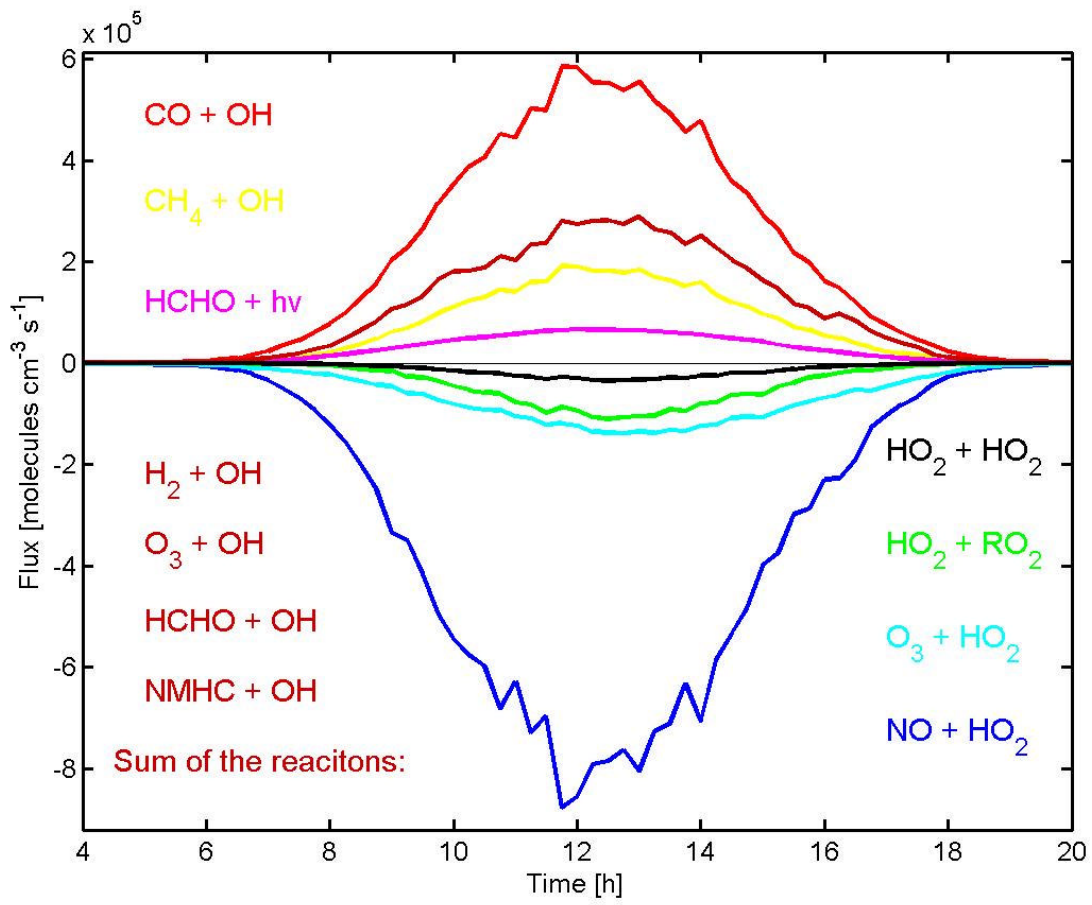

Fig. 7. Same as Fig. 6 for the hydroperoxy radical.
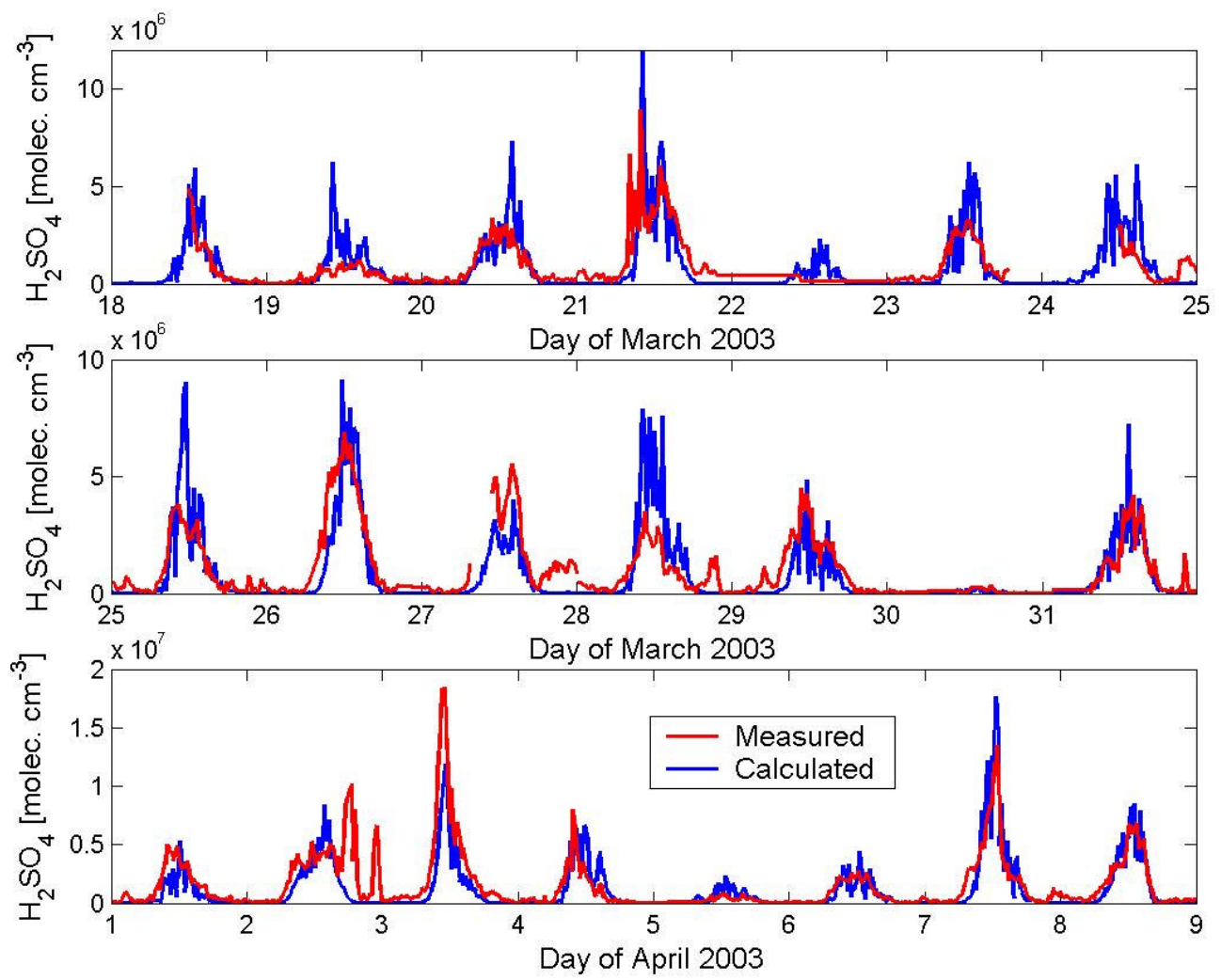

Fig. 8. Measured and calculated sulphuric acid concentrations for Hyytiälä, Finland. 
organic nitrates. Especially during the time when the wind transported higher polluted air masses from the South to Hyytialä the $\mathrm{NO}_{2}$ mixing ratios increased up to $5 \mathrm{ppb}$ and higher. However, no measurements concerning the real nitrogen dioxide fraction exist, and for this reason, we selected during times with high $\mathrm{NO}_{2}$ concentrations two different scenarios $\left(\mathrm{NO}_{2}\right.$-SC I and II, Table 4). The result of these sensitivity studies (SC 6 and 7, Table 4) demonstrates the high effect from the nitrogen dioxide concentration. A decrease of $20 \%$ for $\mathrm{NO}_{2}>1.5 \mathrm{ppb}$ and $40 \%$ for $\mathrm{NO}_{2}>2 \mathrm{ppb}$ increases our calculated sulphuric acid concentrations compared to the measured ones by $18 \%$. We selected a high limit decrease of nitrogen dioxide because of an increased emission of PANs during periods the air masses originated from industrialised areas. The atmospheric lifetime of the PAN-molecules in the temperature range $273-298 \mathrm{~K}$ lies between 0.5 and $8 \mathrm{~h}$ (Seinfeld and Pandis, 1998).

In SC 8 we combined the results by including modified values from two discussed parameters (NMHC were multiplied by a factor of 2 and $\mathrm{NO}_{2}$ were modified by scenario $\mathrm{NO}_{2}$-SC II, see Table 4). The ratio between measurements and calculations reached now a value close to unity and the standard deviation decreased to 0.412 . The results indicate that the selected assumptions produce the best agreement compared with the measured $\mathrm{H}_{2} \mathrm{SO}_{4}$ concentrations. Figure 8 shows the measured and calculated (SC 8, Table 4) sulphuric acid concentrations from the 18 March until the 8 April. The mean daytime ( 6 a.m. to 6 p.m.) correlation coefficient between the two curves (measured and calculated by $\mathrm{SC} 8-\mathrm{H}_{2} \mathrm{SO}_{4}$ ) is 0.645 with a standard deviation of 0.23 . The maximum midday sulphuric acid concentrations varied between $3 \times 10^{5}$ to $1.9 \times 10^{7}$ molecules $\mathrm{cm}^{-3}$ for the measurements and $3 \times 10^{5}$ to $1.4 \times 10^{7}$ molecules $\mathrm{cm}^{-3}$ for the calculations, respectively. Some peaks of $\mathrm{H}_{2} \mathrm{SO}_{4}$ in the evening (e.g. 24, 27, 28 March and 2 April) were not produced in our calculations. However, as mentioned already in Sect. 1 we exclude night time chemistry in this work and therefore our photo stationary model cannot calculate any $\mathrm{OH}$ concentrations after sunset. On some days (e.g. 25 or 28) the calculated sulphuric acid concentrations exceeds the measured ones clearly (factor between 2-4). These days are also the days with the lowest condensation sink values. One explanation might be the fact that during times with low CS-values air masses mostly originated over the Atlantic or Polar region containing high amounts of sea-salt aerosols. These aerosols normally are more hygroscopic compared to particles originated from industrialised regions, like Central Europe or England and so our hygroscopic growth factors would be too small. In the next two sub-sections we will use calculated sulphuric acid concentrations achieved by using the settings of scenario 8 (see Table 4).

According to our results and sensitivity analysis, we can see that the sulphuric acid concentrations can be estimated reasonably. The calculated results are typically within $20(\%)$ of the measured values and almost always within 50(\%) from each other. However, there are cases where the error is potentially much larger. As an overall error estimation we can consider errors related to sinks and sources of sulphuric acid. The source is related to $\mathrm{OH}$ concentration times sulphur dioxide concentration. The error related to $\mathrm{OH}$ concentration is probably within the range of $0.5-2.0$ times the real value (see Table 3), and the error related to $\mathrm{SO}_{2}$ concentration is within $5 \%$. The sink term is actually the condensation sink. In our analysis we have used accommmodation coefficient of unity, and the other sources of error is related to determination of ambient aerosol size distribution. This will cause uncertainty of $20 \%$. Altogether the maximum error in sulphuric acid concentration is in the range of 0.4-2.5 times the actual concentration.

\subsection{Particle growth rates}

With the sulphuric acid concentrations $\left(\mathrm{C}_{\mathrm{H}_{2} \mathrm{SO}_{4}}\right)$, we can now calculate the particle diameter growth rates in the nucleation mode between 3 and $25 \mathrm{~nm}$ (Kulmala et al., 2001b) by

$$
\frac{d D_{p}}{d t}=\frac{m_{\mathrm{H}_{2} \mathrm{SO}_{4}} \cdot \beta_{m} \cdot D_{\mathrm{H}_{2} \mathrm{SO}_{4}} \cdot C_{\mathrm{H}_{2} \mathrm{SO}_{4}}}{D_{p} \cdot \rho_{\mathrm{H}_{2} \mathrm{SO}_{4}}} \text {. }
$$

Here $\mathrm{m}_{\mathrm{H}_{2} \mathrm{SO}_{4}}$ is the molecular mass, $\rho_{\mathrm{H}_{2} \mathrm{SO}_{4}}$ is the liquid density and $D_{\mathrm{H}_{2} \mathrm{SO}_{4}}$ is the diffusion coefficient of sulphuric acid. $\beta_{m}$ is the transitional correction factor for the mass fluxes (Fuchs and Sutugin, 1971) and $D_{p}$ is the particle diameter. Equation (4) can be integrated from $D_{p o}$ to $D_{p}$ to obtain:

$$
\begin{aligned}
& C_{\mathrm{H}_{2} \mathrm{SO}_{4}}= \\
& \rho_{\mathrm{H}_{2} \mathrm{SO}_{4}}\left(\frac{D_{p}^{2}-D_{p o}^{2}}{8}+\left[\frac{4}{3 \alpha}-0.623\right] \cdot \lambda \cdot 0.5 \cdot\left(D_{p}-D_{p_{o}}\right)+\right. \\
& \left.0.623 \cdot \lambda^{2} \cdot \ln \frac{\lambda+D_{p}}{\lambda+D_{p o}}\right) / \Delta_{\mathrm{H}_{2} \mathrm{SO}_{4}} \cdot \mathrm{m}_{\mathrm{H}_{2} \mathrm{SO}_{4}} .
\end{aligned}
$$

Here, $\alpha$ is accommodation coefficient (i.e. sticking probability, a value of one were used for all particles and conditions in this work), $\lambda$ is the mean free path of the sulphuric acid molecules and $\Delta \mathrm{t}$ is the time step.

Table 5 gives the growth rates based on particle number size distributions from DMPS-measurements and the growth rates determined with Eq. (4) from measured and calculated sulphuric acid concentrations for all days, when high amounts of small particles above $3 \mathrm{~nm}$ were visible on the DMPS-plots (particle formation periods). The growth rates from the DMPS data plots were estimated visually. Due to the somewhat inaccurate nature of this method, an uncertainty by a factor of two has to be taken into account.

Boy et al. (2003) estimated a growth rate fraction for sulphuric acid of $4-31 \%$ by analysing two years of data from the field station in Hyytiälä, Finland. Both growth rate fractions determined with the measured and calculated sulphuric acid concentrations are in the lower range of this earlier estimations $\left(\mathrm{d} D_{p} / \mathrm{dt}_{\text {average }}=8.8 \%\right)$. The result indicate, that the concentration of sulphuric acid seems always to be high enough 
Table 5. Particle growth rates for several days during the campaign achieved by: DMPS=based on measured particle number concentration with size distribution; $\left[\mathrm{H}_{2} \mathrm{SO}_{4}-\mathrm{M}\right]=$ based on measured sulphuric acid concentrations and $\left[\mathrm{H}_{2} \mathrm{SO}_{4}-\mathrm{C}\right]=$ based on calculated sulphuric acid concentration. The later ones are calculated through Eq. (3). Air mass classification: P="polluted days" and C="clean days" (see Sect. 3).

\begin{tabular}{|c|c|c|c|c|c|c|c|c|}
\hline \multirow[b]{2}{*}{ Date } & \multirow{2}{*}{$\begin{array}{l}\text { Air mass } \\
\text { classi- } \\
\text { fication }\end{array}$} & \multirow{2}{*}{$\begin{array}{c}\text { GR } \\
\text { DMPS } \\
{\left[\mathrm{nm} \mathrm{h}^{-1}\right]}\end{array}$} & \multicolumn{2}{|c|}{ Measurements } & \multicolumn{2}{|c|}{ Calculations } & \multirow{2}{*}{$\begin{array}{c}\mathrm{GR}\left(\mathrm{H}_{2} \mathrm{SO}_{4}-\mathrm{M}\right) \\
/ \mathrm{GR}(\mathrm{DMPS}) \\
{[\%]}\end{array}$} & \multirow{2}{*}{$\begin{array}{c}\mathrm{GR}\left(\mathrm{H}_{2} \mathrm{SO}_{4}-\mathrm{C}\right) \\
/ \mathrm{GR}(\mathrm{DMPS}) \\
{[\%]}\end{array}$} \\
\hline & & & $\begin{array}{c}{\left[\mathrm{H}_{2} \mathrm{SO}_{4}\right]} \\
{\left[\mathrm{mol} . \mathrm{cm}^{-3}\right]}\end{array}$ & $\begin{array}{c}\mathrm{GR}\left(\mathrm{H}_{2} \mathrm{SO}_{4}-\mathrm{M}\right) \\
{\left[\mathrm{nm} \mathrm{h}^{-1}\right]}\end{array}$ & $\begin{array}{c}{\left[\mathrm{H}_{2} \mathrm{SO}_{4}\right]} \\
{\left[\mathrm{mol} . \mathrm{cm}^{-3}\right]}\end{array}$ & $\begin{array}{c}\mathrm{GR}\left(\mathrm{H}_{2} \mathrm{SO}_{4}-\mathrm{C}\right) \\
{\left[\mathrm{nm} \mathrm{h}^{-1}\right]}\end{array}$ & & \\
\hline 19.3.2003 & C & 1,0 & $7,18 \mathrm{E}+05$ & 0,06 & $1,23 \mathrm{E}+06$ & 0,10 & 6,1 & 10,5 \\
\hline 20.3.2003 & C & 1,5 & $1,82 \mathrm{E}+06$ & 0,15 & $2,26 \mathrm{E}+06$ & 0,19 & 10,2 & 12,6 \\
\hline 21.3.2003 & $\mathbf{P}$ & 2,6 & $2,81 \mathrm{E}+06$ & 0,24 & $2,62 \mathrm{E}+06$ & 0,22 & 9,1 & 8,5 \\
\hline 25.3.2003 & C & 2,5 & $1,78 \mathrm{E}+06$ & 0,15 & $2,29 \mathrm{E}+06$ & 0,20 & 6,1 & 7,8 \\
\hline 26.3.2003 & $\mathbf{P}$ & 3,6 & $3,62 E+06$ & 0,31 & $3,20 E+06$ & 0,28 & 8,6 & 7,6 \\
\hline 29.3.2003 & $\mathbf{P}$ & 3,6 & $2,03 E+06$ & 0,17 & $1,34 \mathrm{E}+06$ & 0,12 & 4,8 & 3,2 \\
\hline 31.3.2003 & C & 3,5 & $2,77 \mathrm{E}+06$ & 0,23 & $2,70 \mathrm{E}+06$ & 0,23 & 6,7 & 6,5 \\
\hline 2.4.2003 & $\mathbf{P}$ & 2,4 & $4,79 \mathrm{E}+06$ & 0,40 & $3,05 \mathrm{E}+06$ & 0,26 & 16,9 & 10,7 \\
\hline 3.4.2003 & $\mathbf{P}$ & 3,8 & $3,28 \mathrm{E}+06$ & 0,28 & $1,88 \mathrm{E}+06$ & 0,16 & 7,3 & 4,2 \\
\hline 6.4.2003 & C & 1,8 & $1,86 \mathrm{E}+06$ & 0,16 & $1,72 \mathrm{E}+06$ & 0,15 & 8,7 & 8,1 \\
\hline 7.4.2003 & C & 2,9 & $4,62 E+06$ & 0,39 & $5,15 \mathrm{E}+06$ & 0,44 & 13,5 & 15,0 \\
\hline Average & & 2,7 & $2,74 E+06$ & 0,2 & $2,50 E+06$ & 0,2 & 8,9 & 8,6 \\
\hline
\end{tabular}

during particle formation periods to participate in the growth process of the aerosols and can reach on certain days fractions up to $17 \%$ and most probably higher.

\subsection{Air mass influences}

In the last sub-section we will use the air mass classification discussed in Sect. 3 and investigate the trend of certain parameters under different aerosol loads. Hereby we will only use these days from the classification from Sect. 3 where particle formation occurred (see Table 5). Table 6 present the event-time (particle formation periods) averages for several gases, the condensational sink and the growth rates as mean values during the "clean" and "polluted" air mass periods. The high anthropogenic influence during the more polluted days was reflected in two to six times higher concentrations of $\mathrm{SO}_{2}, \mathrm{NO}_{2}$ and NO. Traffic, industry and households mostly emitted these species. Ozone and carbon monoxide are approximately in the same range in both air mass classes. Mainly the combination of six times lower NO concentrations - main source term of the $\mathrm{OH}$ radicals - and three times lower $\mathrm{NO}_{2}$ concentrations - beside $\mathrm{CO}$, the second important sink term of the $\mathrm{OH}$ radicals - led to a nearly equal concentration of hydroxyl radicals in "clean" and "polluted" air masses. Carslaw et al. (2002) presented measured $\mathrm{OH}$ and $\mathrm{HO}_{2}$ concentrations at Mace Head, Ireland for air masses originated from France, UK and Polar regions. Their results agree with ours in that the hydroxyl radical concentrations in all air masses are about equal and that the hydroperoxy radical concentrations are approximately double during the periods the air originated from the Northern regions.

Concerning the "clean" and "polluted" air masses, 2.6 times lower CS values during the times when the air orig- inated over the Atlantic or the Polar region was detected, which reflects the higher load of aerosols during days when the air masses are originated from more industrialised regions. The difference of this parameter combined with three times higher concentrations of sulphur dioxide during more polluted periods resulted in about equal sulphuric acid concentrations in our calculations; the measured $\mathrm{H}_{2} \mathrm{SO}_{4}$ concentrations led to a slightly higher ratio ("polluted"$\mathrm{H}_{2} \mathrm{SO}_{4}$ /"clean"- $\mathrm{H}_{2} \mathrm{SO}_{4}=1.46$ ). The difference of $46 \%$ in the $\mathrm{H}_{2} \mathrm{SO}_{4}$ concentrations between the calculations and measurements could result from different compositions of the aerosols and consequently different hygroscopic growth factors. Especially during the "polluted" periods, high amounts of soot particles with growth factors close to unity are accompanied. The effect of such low hygroscopicity aerosols results in lower CS-values, and consequently, in higher sulphuric acid concentrations.

Concerning the growth rates of particles, a 1.5 times higher value was determined with measured aerosol number size distributions during days when the air originated from Central Europe or UK. The fact that clear particle formation events occur more often during days with less aerosol load was pointed out in many publications like e.g. Boy and Kulmala (2002b) or Clement et al. (2001). However, the nearly identical contribution of sulphuric acid to the particle growth during the "polluted" periods compared to the "clean" days is unexpected. These results indicate that sulphuric acid always participated during the time of the campaign between 3 to $17 \%$ in the aerosol condensation growth of the nucleation mode particles. 
Table 6. Certain measured and calculated parameters divided by air mass classification discussed in Sect. 3 (NO 2 -SC II and CS-SC II see Table 4; GR classes see Table 5).

\begin{tabular}{|c|c|c|c|}
\hline Parmaters & Unit & $\begin{array}{l}\text { Clean air } \\
\text { masses }\end{array}$ & $\begin{array}{l}\text { Polluted } \\
\text { air masses }\end{array}$ \\
\hline \multicolumn{4}{|l|}{ Gas concentrations } \\
\hline CO & molec. $\mathrm{cm}^{-3}$ & $3,93 \mathrm{E}+12$ & $4,09 \mathrm{E}+12$ \\
\hline $\mathrm{O}_{3}$ & molec. $\mathrm{cm}^{-3}$ & $1,00 \mathrm{E}+12$ & $1,09 \mathrm{E}+12$ \\
\hline $\mathrm{NO}_{2}-\mathrm{SC}-\mathrm{II}$ & molec. $\mathrm{cm}^{-3}$ & $1,72 \mathrm{E}+10$ & $4,16 \mathrm{E}+10$ \\
\hline $\mathrm{SO}_{2}$ & molec. $\mathrm{cm}^{-3}$ & $6,07 \mathrm{E}+09$ & $1,74 \mathrm{E}+10$ \\
\hline NMHC & molec. $\mathrm{cm}^{-3}$ & $6,37 \mathrm{E}+08$ & $2,91 \mathrm{E}+09$ \\
\hline NO & molec. $\mathrm{cm}^{-3}$ & $7,91 \mathrm{E}+08$ & $4,68 \mathrm{E}+09$ \\
\hline \multicolumn{4}{|l|}{ Radical concentrations } \\
\hline $\mathrm{OH}$ & molec. $\mathrm{cm}^{-3}$ & $5,13 E+05$ & $4,64 \mathrm{E}+05$ \\
\hline $\mathrm{HO}_{2}$ & molec. $\mathrm{cm}^{-3}$ & $5,79 \mathrm{E}+07$ & $1,89 \mathrm{E}+07$ \\
\hline \multicolumn{4}{|l|}{ Condensational sink } \\
\hline CS-SC II & $s^{-1}$ & 1,10E-03 & $2,90 \mathrm{E}-03$ \\
\hline \multicolumn{4}{|l|}{ Sulfuric acid concentration } \\
\hline Calculated & molec. $\mathrm{cm}^{-3}$ & $2,56 \mathrm{E}+06$ & $2,42 E+06$ \\
\hline Measured & molec. $\mathrm{cm}^{-3}$ & $2,26 \mathrm{E}+06$ & $3,31 \mathrm{E}+06$ \\
\hline \multicolumn{4}{|l|}{ Growth rates } \\
\hline $\mathrm{GR}\left[\mathrm{H}_{2} \mathrm{SO}_{4}-\mathrm{M}\right]$ & $\mathrm{nm} \mathrm{h}^{-1}$ & 0,19 & 0,28 \\
\hline $\mathrm{GR}\left[\mathrm{H}_{2} \mathrm{SO}_{4}-\mathrm{C}\right]$ & $\mathrm{nm} \mathrm{h} \mathrm{h}^{-1}$ & 0,22 & 0,21 \\
\hline GR [DMPS] & $\mathrm{nm} \mathrm{h}^{-1}$ & 2,20 & 3,20 \\
\hline $\mathrm{GR}\left[\mathrm{H}_{2} \mathrm{SO}_{4}-\mathrm{M}\right] / \mathrm{GR}$ [DMPS] & $\%$ & 8,68 & 8,78 \\
\hline $\mathrm{GR}\left[\mathrm{H}_{2} \mathrm{SO}_{4}-\mathrm{C}\right] / \mathrm{GR}$ [DMPS] & $\%$ & 9,84 & 6,43 \\
\hline
\end{tabular}

\section{Summary and conclusions}

In this work, we used measurements from the QUEST field campaign conducted in Hyytiälä during March and April 2003. Among many other parameters, sulphuric acid was measured continuously on 21 days. We concentrated our analyses on daytimes ( 9 a.m.-3 p.m.) during this period. The measured concentrations were compared with calculated ones, achieved by a simple pseudo steady state box model including photo stationary states. Further, we estimated the particle growth rates for the nucleation mode aerosols determined by measured particle number concentrations with size distributions and from the concentrations of sulphuric acid. In the end, we classified the days with air masses originated from Europe or UK and from the Atlantic or Polar region to investigate the influence of several variables on the $\mathrm{OH}$ and $\mathrm{H}_{2} \mathrm{SO}_{4}$ concentrations and on the particle growth rates.

As a first result we presented the importance of the various sink and source terms in the $\mathrm{OH}$ and $\mathrm{HO}_{2}$ radical balance as mean values for the selected time. Nitrogen oxide was the dominant source term (mean contribution $=55.9 \%$ ) and carbon monoxide the key sink term (mean contribution=41\%) in the hydroxyl radical balance. The same two components play also the major role in the hydroperoxy radical balance with opposite signs (mean source contribution by $\mathrm{CO}=53.8 \%$ and sink by $\mathrm{NO}=75.7 \%$ ). The daily maxima for the $\mathrm{OH}$ and the $\mathrm{HO}_{2}$ species are in agreement with earlier model calculations by Hakola et al. (2003) for the same site, with values of $4.1 \times 10^{5}$ to $1.8 \times 10^{6}$ molecules $\mathrm{cm}^{-3}$, and $1 \times 10^{7}$ to $1.5 \times 10^{8}$ molecules $\mathrm{cm}^{-3}$, respectively.

In sensitivity studies we investigated the influence of nonmethane hydrocarobons, peroxy radicals and nitrogen dioxide on the concentration of sulphuric acid. By comparing our calculated values of sulphuric acid with the measured ones, we gained the best agreement by decreasing the nitrogen dioxide concentrations during periods when high-polluted air arrived at the SMEAR II station from south to south-east, and by doubling the NMHCs. Using these assumptions, the mean ratio for the whole period between measured and calculated $\mathrm{H}_{2} \mathrm{SO}_{4}$ concentrations reached a value close to unity with a standard deviation of 0.412 . The investigated sulphuric acid closure thus achieved a high agreement between the calculated and measured sulphuric acid concentrations. 
With the measured and calculated sulphuric acid concentrations, we calculated particle diameter growth rates. In addition we estimated the particle growth rates through the DMPS data and defined the contribution of sulfuric acid to the particle growth rates. The average value of $8.8 \%$ were in the lower range of earlier estimations by Boy et al. (2003) for the same site (4-31\%). This indicates that the concentration of sulphuric acid seems always to be high enough during particle formation periods to participate in the growth process of the aerosols and can reach on certain days fractions up to $17 \%$ and most probably higher.

We classified days in two categories by using measurements and $72 \mathrm{~h}$ back trajectories from HYSPLIT:

- Polluted air masses originated over Central $\mathrm{Eu}$ rope or UK with high concentrations of $\mathrm{SO}_{2}, \mathrm{NO}_{2}$ and NO ( average: $1.74 \times 10^{10}, 4.16 \times 10^{10}$ and $4.68 \times 10^{9}$ molecules $\mathrm{cm}^{-3}$, respectively) and also high CS values (average $0.0029 \mathrm{~s}^{-1}$ ).

- "Clean" air masses originated over the North Atlantic or Polar region with 2 to 6 times smaller $\mathrm{SO}_{2}, \mathrm{NO}_{2}$ and NO concentrations (average: $6.07 \times 10^{9}, 1.72 \times 10^{10}$ and $7.91 \times 10^{8}$ molecules $\mathrm{cm}^{-3}$, respectively) and about 2 to 3 times smaller CS values (average $0.0011 \mathrm{~s}^{-1}$ ).

The results of this analysis showed, that the growth rates determined by DMPS-measurements during "polluted" air periods are by a factor of 1.45 higher compared to the "cleaner" days. The contribution of sulphuric acid to the growth rates is approximately equal. Obviously sulfuric acid is involved (fraction between 3 to 17\%) in new particle production and growth of aerosols over boreal forest regions in Northern Europe, although it might be not the key parameter in the particle formation process itself.

Acknowledgements. The QUEST team acknowledge the financial support from the European Commission under the contract number EVK2-CT2001-00127 and the Academy of Finland. Further, the authors gratefully acknowledge the NOAA Air Resources Laboratory (ARL) for the provision of the HYSPLIT transport and dispersion model and/or READY website (http://www.arl.noaa.gov/ready.html) used in this publication.

Edited by: A. Laaksonen

\section{References}

Boy, M. and Kulmala, M.: The part of the solar spectrum with the highest influence of the formation of SOA in the continental boundary layer, Atmos. Chem. Phys., 2, 375-386, 2002a,

SRef-ID: 1680-7324/acp/2002-2-375.

Boy, M. and Kulmala, M.: Nucleation events in the continental boundary layer: Influence of physical and meteorological parameters, Atmos. Chem. Phys., 2, 1-16, 2002b,

SRef-ID: 1680-7324/acp/2002-2-1.
Boy, M., Rannik, Ü., Lehtinen, K. E. J., Tarvainen, V., Hakola, H., and Kulmala, M.: Nucleation events in the continental PBL long term statistical analyses of aerosol relevant characteristics, J. Geophys. Res., 108(D21), 4667, doi:10.1029/2003JD003838, 2003.

Cantrell, C. A., Shetter, R. E., Gilpin, T. M., and Calvert, J. G.: Peroxy radicals measured during Mauna Loa Observatory Photochemistry Experiment 2 - The data and first analysis, J. Geophys. Res., 101, 14 643-14 652, 1996.

Cantrell, C. A., Shetter, R. E., Calvert, J. G., Eisele, F. L., Williams, E., Baumann, K., Brune, W. H., Stevens, P. S., and Mather, J. H.: Peroxy radicals from photostationary state deviations and steady state calculations during the Tropospheric $\mathrm{OH}$ Photochemistry Experiment at Idaho Hill, Colorado, J. Geophys. Res. 102, 6369-6378, 1997.

Carslaw, N., Creasey, D. J., Heard, D. E., Jacobs, P. J., Lee, J. D., Lewis, A. C., McQuaid, J. B., Pilling, M. J., Bauguitte, S., Penkett, A., Monks, P. S., and Salibury, G.: Eastern Atlantic Spring Experiment 1997 (EASE97), 2. Comparisons of model concentrations of $\mathrm{OH}, \mathrm{HO} 2$, and $\mathrm{RO} 2$ and measurements, J. Geophys. Res. 107(D14), 4190, doi:10.1029/2001JD001568, 2002.

DeMore, W. G., Sander, S. P., Golden, D. M., Hampson, R. F., Kurylo, M. J., Howard, C. J., Ravishankara, A. R., Kolb, C. E., and Molina, M. J.: Chemical Kinetics and Photochemical Data for use in Stratospheric Modelling, Evaluation No. 11, JPL Publication 94-26, Jet Propulsion Laboratory, Pasadena, CA, 1994.

Eisele F. L. and Tanner D. J.: Measurement of the gas phase concentration of $\mathrm{H}_{2} \mathrm{SO}_{4}$ and methane sulfonic acid and estimates of $\mathrm{H}_{2} \mathrm{SO}_{4}$ production and loss in the atmosphere, J. Geophys. Res., 98(D5), 9001-9010, 1993.

Fuchs, N. A. and Sutugin, A. G.: Highly dispersed aerosol, in: Topics in current aerosol research, edited by: Hidy, G. M. and Brock, J. R., Pergamon, New York, 1971.

Hämeri, K., Väkevä, M., Aalto, P., Kulmala, M., Swietlicki, E., Zhou, J., Seidl, W., Becker, E., and O'Dowd, C. D.: Hygroscopic and $\mathrm{CCN}$ properites of aerosol particles in boreal forest, Tellus 53 B, 345-359, 2001

Hakola, H., Tarvainen, V., Laurila, T., Hiltunen, V., Hellén, H., and Keronen, P.: Seasonal variation of VOC concentrations above a boreal coniferous forest, Atmos. Environ., 37(12), 1623-1634, 2003.

Handisides, G. M., Plass-Dülmer, C., Gilge, S., Bingemer, H., and Berresheim, H.: Hohenpeissenberg Photochemical Experiment (HOPE 2000): Measurements and photostationary state calculations of $\mathrm{OH}$ and peroxy radicals, Atmos. Chem. Phys., 3, 15651588, 2003,

SRef-ID: 1680-7324/acp/2003-3-1565.

Hanke, M., Uecker, J., Reiner, T., and Arnold, F.: Atmospheric peroxy radicals: ROXMAS, a new mass-spectrometric methodology for speciated measurements of $\mathrm{HO} 2$ and Sigma $\mathrm{RO} 2$ and first results, International Journal of Mass Spectrometry, 213(23), 91-99, 2002.

Hellén, H., Hakola H., Reissell A., and Ruuskanen T. M.: Carbonyl compounds in boreal coniferous forest air in Hyytiälä, Southern Finland, Atmos. Chem. Phys., 4, 1771-1780, 2004, SRef-ID: 1680-7324/acp/2004-4-1771.

Janson, R. and De Serves, C.: Isoprene emissions from boreal wetlands in Scandinavia, J. Geophys. Res., 103(D19), 25513 $25517,1998$. 
Korhonen, P., Kulmala, M., Laaksonen, A., Viisanen, Y., McGraw, R., and Seinfeld, J. H.: Ternary nucleation of $\mathrm{H} 2 \mathrm{SO} 4, \mathrm{NH} 3$ and $\mathrm{H} 2 \mathrm{O}$ in the atmosphere, J. Geophys. Res., 104, 26349-26353, 1999.

Kulmala, M., Hämeri, K. K., Aalto, P., Mäkelä, J., Pirjola, L., Nilsson, E. D., Buzorius, G., Rannik, Ü., Dal Maso, M., Seidl, W., Hoffmann, T., Jansson, R., Hansson, H.-C., O'Dowd, C., and Viisanen, Y.: Overview of the international project on biogenic aerosol formation in the boreal forest (BIOFOR), Tellus B, 53, 324-343, 2001a.

Kulmala, M., Dal Maso, M., Mäkelä, J. M., Pirjola, L., Väkevä, M., Aalto, P., Miikkulainen, P., Hämeri, K., and O'Dowd, C.: On the formation, growth and composition of nucleation mode particles, Tellus B, 53, 479-490, 2001b.

Kulmala, M.: How particles nucleate and grow, Science, 307(5647), 1000-1001, 2003.

Kulmala, M., Vehkamäki, H., Petäjä, T., Dal Maso, M., Lauri, A., Kerminen, V.-M., Birmili, W., and McMurry, P. H.: Formation and growth rates of ultrafine atmospheric particles: A review of observations, J. Aerosol Sci, 35, 2, 143-176, 2004a.

Kulmala, M., Kerminen, V.-M., Anttila, T., Laaksonen, A., and O'Dowd, C.: Organic aerosol formation via sulphate cluster activation, J. Geophys. Res., 109, D04205, doi:10.1029/2003JD003961, 2004b.

Menon, S., Del Genio, A. D., Koch, D., and Tselioudis, G.: GCM simulations of the aerosol indirect effect: Sensitivity to cloud parameterization and aerosol burden, J. Atmos. Sci., 59, 692713, 2002.

Ramanathan, V., Crutzen, P. J., Kiehl, J. T., and Rosenfeld, D.: Aerosol, climate, and the hydrological cycle, Science, 294, 2119-2124, 2001.
Rolph, G. D.: Real-time Environmental Applications and Display sYstem (READY) Website (http://www.arl.noaa.gov/ready/ hysplit4.html), NOAA Air Resources Laboratory, Silver Spring, MD, 2003.

Seinfeld, J. H. and Pandis, S. N.: Atmospheric chemistry and physic, John Wiley \& Sons, New York, 1998.

Sellegri, K., Umann, B., Hanke, M., and Arnold, F.: Deployment of a ground-based CIMS apparatus for the detection of organic gases in the boreal forest during the QUEST campaign, Atmos. Chem. Phys., 5, 357-372, 2005.

Solberg, S., Dye, C., Roemer, M., and Schmidbauer, N.: VOC measurements 1999, EMEP/CCC Report 7, 2001.

Stieb, D. M., Judek, S., and Burnett, R. T.: Meta-analysis of timeseries studies of air pollution and mortality: Effects of gases and particles and their influence of cause of death, age and season. J. Air \& Manage. Assoc. 52, 470-484, 2002.

Swietlicki, E., Zhou, J., Covert, D. S., Hämeri, K., Busch, B., Väkeva, M., Dusek, U., Berg, O. H., Wiedensohler, A., Aalto, P., Mäkelä, J., Martinsson, B. G., Papaspiropoulos, G., Mentes, B., Frank, G., and Stratmann, F.: Hygroscopic properties of aerosols in the north-eastern Atlantic during ACE-2, Tellus 52 B, 201227, 2000.

Weber, R. J., Marti, J. J., McMurry, P. H., Eisele, F. L., Tanner, D. J., and Jefferson, A.: Measurements of new particle formation and ultrafine particle growth rates at a clean continental site, J. Geophys. Res., 102, 4375-4385, 1997.

Wichmann, H.-H. and Peters, A.: Epidemiological evidence of the effects of ultrafine particle exposure, Phil. Trans. R. Soc. Lond., A., 358, 2751-2769, 2000. 